Portland State University

PDXScholar

$1-1-2011$

\title{
The Responsibilities and Limitations of Holocaust Storytelling: Understanding the Structure and Usage of the Master Narrative in Holocaust Film
}

Fianna Raven MacGregor

Portland State University

Follow this and additional works at: https://pdxscholar.library.pdx.edu/open_access_etds Let us know how access to this document benefits you.

\section{Recommended Citation}

MacGregor, Fianna Raven, "The Responsibilities and Limitations of Holocaust Storytelling: Understanding the Structure and Usage of the Master Narrative in Holocaust Film" (2011). Dissertations and Theses. Paper 150.

https://doi.org/10.15760/etd.150

This Thesis is brought to you for free and open access. It has been accepted for inclusion in Dissertations and Theses by an authorized administrator of PDXScholar. Please contact us if we can make this document more accessible: pdxscholar@pdx.edu. 
The Responsibilities and Limitations of Holocaust Storytelling: Understanding the Structure and Usage of the Master Narrative in Holocaust Film

$$
\text { by }
$$

\title{
Fianna Raven MacGregor
}

A thesis submitted in partial fulfillment of the requirements for the degree of

\author{
Master of Arts \\ in \\ Interdisciplinary Studies
}

Thesis Committee:

William Tate, Chair

Michael Clark

Karen Popp

Portland State University

(C)2011 


\begin{abstract}
When we speak of historical events, we do so with a certain amount of perceived knowledge; that is, we come to believe we know specific, individual 'truths' about the event. Since historical works are never unembellished lists of documented facts, the knowledge of how we conceive of factual events, how we document events we did not witness, is important in understanding the resulting storytelling process, not just in fictional literary constructs such as novels, short stories, poetry or film, but in the formulation of history itself. For written history must be seen, at least in part, as a constructed or representational reality and this construction generally takes place organically, that is, there are no architects of such histories. Instead, they come together as a result of public acceptance of the individual elements of the narrative. Over time, historical data and anecdotal narrative solidify into a cohesive whole made up of both hard fact and individual response to those facts, a blended whole that can be termed the master narrative of the historical event and which serves as the basis on which we construct the fictional narratives of literature and film.
\end{abstract}


For my father, Jerry Burton, who didn't get to do this, and for Walter Beach, who never stops believing in me 
Table of Contents

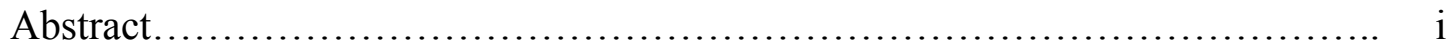

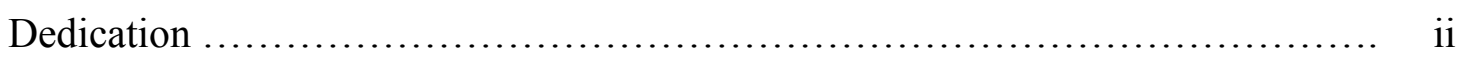

Chapter One:

Introduction................................................................ 1

Chapter Two:

Defining the Master Narrative in General Storytelling........................ 10

Chapter Three:

A Documentation of the Master Narrative Specific to the Holocaust as a Historic

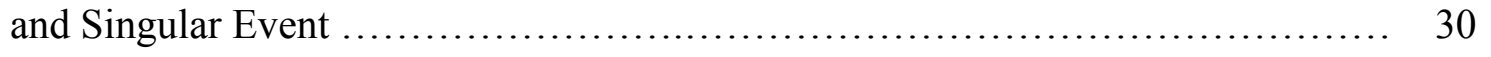

Chapter Four:

A Study of Documentaries and Fictional Film in Relation to the Holocaust Master Narrative and Its Effects on Storyline.................................. 54

A. Documentaries.................................................. 55

B. Fictional Cinematic Representations............................ 67

Chapter Five:

The Signifier Signifying Nothing: The Rhetoric of the Unspeakable in Holocaust Discourse....................................................................... 79

Chapter Six:

Conclusion........................................................... 89

References...................................................... 92 
Chapter One: Introduction

When we speak of historical events, we do so with a certain amount of perceived knowledge; that is, we come to believe we know specific, individual 'truths' about the event. But what do we really know about history? How do we formulate opinions about the events of the past? The phenomenon by which historical events become part of public memory and how the resulting compilation of information becomes what will hereafter be referred to as the master narrative, will be addressed in this thesis. Since historical works are never unembellished lists of documented facts, the knowledge of how we conceive of factual events, that is, how we document events we did not witness, is important in understanding the resulting storytelling process, not just in fictional literary constructs such as novels, short stories, poetry or film, but also in the formulation of history itself. Written history must be seen, at least in part, as a constructed or representational reality and this construction, although based on the review and acceptance of factual data by professional historians, does not include all available facts in the completed product. The historian chooses factual evidence based on the particular piece of history he is attempting to record. In contrast, the master narrative, though equally representational, does not rely solely on empirical evidence. Instead, such publicly held notions of history congeal as a result of public acceptance of the individual elements of the narrative. Over time, historical data and anecdotal narrative solidify into a cohesive whole made up of both hard fact and individual 
response to those facts, a blending of related ideas that can be termed the master narrative of the historical event and which serves as the basis on which we construct the fictional narratives of literature and film. But how does the master narrative differ from history? That is, can we use historical account and the master narrative interchangeably?

Prior to the mid-1800s, history was not seen as a discipline unto itself, rather, one studied the classics in order to understand history, literature and philosophy as a whole. Once history became a discrete unit of study, the tendency was to believe that the events of the past should be studied in a completely objective way; history was viewed as "simply a science, no less and no more." The belief was that historians could and would remove themselves from the equation and report events without embellishment, emotion or human interference. However, this type of unyielding empirical study of history left the human element by the wayside. In other words, in order to avoid tainting the documentation of objective history the human subject was removed, and geology, economics and political history were studied without reference to the impact on society as a whole, or the individual in particular. However, by the 1930's, the French Annales School of thought stated that when one studies history, it should be done as an "integrated, total history" (Lambert, 78) which accounts for the human element, otherwise the historical record will be incomplete. Therewith, the

\footnotetext{
${ }^{1}$ J.B. Bury. Quoted in Lambert's Making History, p.26. It is also important here to state that what is being called history is written history. Oral history as a tradition of all human cultures is separate from this debate and, although it can, in fact, contribute to the master narrative and can also be the primary source of it, in this context oral and written history cannot be considered alike in that they have different sets of rules governing their acceptance as reliable sources of history.
} 
transformation was made from documenting "that there was a past" to "what the past was like.” (Stanford, 49)

However, the problems connected with the impossibility of total objectivity in the documentation of history were soon replaced with a new set of difficulties. If the human element is added to the cataloguing of empirical data, there must, out of necessity, be interpretation, and where there is interpretation, there is debate over the correctness of each and every version. Since no historian can be seen as the definitive authority on any given piece of history, historians must be understood to write about events based not only on whether evidence "is true or false but [also on] what it means." (Stanford, 77) The historian, then, injects himself into historical record by drawing conclusions of meaning with relation to the documentary evidence. The current debate centers on the extent to which the historian's own prejudices, beliefs and opinions should color historical record. One side of the debate promotes a positivistic ideal, wherein the historian attempts to keep the history he is writing as free as possible from his own biases, believing that he can record events by using his expertise in the field to compile the data in a logical or meaningful way, and admitting ignorance in the face of missing evidence. The opposing view allows an imaginative approach wherein the historian may pick and choose amongst events which fit a particular theory and may reconstruct his own version of any event for which there is no record. (Stanford, 76-87)

Further, Robert Brent Toplin and Jason Eudy discuss the ways in which history, regardless of the medium used to compile it, becomes a means of thinking 
about and analyzing the past and that this process cannot be viewed as wholly objective. They therefore argue that history is an endeavor located somewhere between the positivistic and imaginative approaches. "Historical interpretation involves the arranging and shaping of stories, not the objective representations of truth. All historical explanations involve considerable exercise of creative license, even traditional modes of interpretation through books and articles.” (Toplin, 8) Therefore, what we know or don't know is the result of the interpretation of facts at the hands of historians, which comes to be known as historical reality regardless of the use of either the positivistic or imaginative definition of interpretation. Therefore, the interpretation of fact and the facts on which any interpretation is based cannot be considered the same, since the reality created by interpretation is the result of the filtering of evidentiary facts and data through the biases and personal experiences of the individual doing the interpreting, as well as through the larger overall historical discourse. ${ }^{2}$ Similarly, the interpretation of history for written documentation and the formulation of the master narrative cannot be seen as the same.

Historical record, that is, the study of history, remains an attempt to document events without the emotional interference of the subject being studied. While historians may claim license to invent missing data if they feel it is warranted, they do not claim to allow the subject to interpret the data for them. The master narrative knows no such restrictions. Since there is no author of the master narrative, as such, and the data collection depends on public acceptance rather than interpretation by

2 Foucault's On the Ways of Writing History discusses the ways in which history is written through that which has been written before. 
professional historians, the appearance of individual elements in the master narrative is entirely subjective. The master narrative for each event certainly contains historical evidence, but is not limited to empirical data nor to the interpretation of that data. Instead, it may contain any number of additional elements and may, in fact, discard historical data already accepted as fact. Hence, when authors and filmmakers, either consciously or unconsciously, use this master narrative made up of fact, interpretation and publicly held opinion as a matrix on which to build a believable story, they are, as Plato would argue, creating a representation of a representation. This representational reality may not be strictly factual but nonetheless is true in that the narrative may tell a story which consists of symbolic or metaphoric truths where facts alone are unable to convey the necessary emotion. Since the fictional representations of film and literature necessarily attempt to appeal to human emotion in order to fully engage the audience in the experience, the matrix on which the stories are based must include human experience in addition to scientific data and we must allow that the human element may, in fact, comprise the larger part of the narrative.

How this master narrative comes to be formed will be discussed in Chapter Two, while Chapter Three will document the specifics of its use as the basis of knowledge pertaining to the Holocaust as a genocidal event but also as an unparalleled traumatic event in human history. What do we, as a contemporary global population, believe we know about the Holocaust? How do we recognize when a particular Holocaust story is 'accurate' and how is that accuracy measured? What elements must be present in order to tell a story of the Holocaust? The Holocaust is not only distinct 
in history, but singular in the ways in which its master narrative has been constructed. The unusual place that the Holocaust, as a genocidal event, holds in history is due not only to the record number of human deaths at the hands of a single governmental body, but also because the event itself marks a place on the historic timeline of the world as a whole, wherein the past, that is, what came before the Holocaust, and future, anything which occurred after the Holocaust, had to be viewed through different lenses. Theodor Adorno is often quoted as saying, "To write poetry after Auschwitz is barbaric" (xv-xvi), however, he is misquoted, or at least, not adequately so. If we look at the entirety of the passage from which this statement is taken, we can understand he meant that the continuation of unmodified cultural history in the wake of an event such as the Holocaust was impossible, that we had entered a new era of barbarism and, in many areas of cultural expression, such as poetry and art, we must start afresh. As Lawrence Langer states, "We are still wrestling with the loss of stature that a disaster like the Holocaust imposes on our ideal of civilization." (5) This diversion of the timeline into a new reality which must include knowledge of the Nazi death camps, meant that not only could world consciousness not return to the place of relative innocence that we had occupied before the Holocaust, but that the annihilation of millions of people had undoubtedly meant the loss of important contributors to our cultural future. How, then, do we begin to understand the scope of the Holocaust and its implications through a tool such as the historical master narrative which, as only a starting point for understanding history, cannot include all the details of the horrors of 
the that which it represents? How does the paucity of information on the myriad individual stories make the master narrative both problematic and necessary?

Even in the rarified history of genocide, the Holocaust gives rise to controversy as historians and laypeople alike question the accuracy, legitimacy and ownership of Holocaust storytelling, an atmosphere compounded by the fact that survivors found themselves unable to discuss their experiences following liberation from the camps. As survivors emerged, they were encouraged by liberating troops, Jews in diaspora and bystanders of the atrocities, not to speak of their experiences. In fact, the end of the war and abandonment of the camps did not stop rampant anti-Semitism in Europe. Survivors quickly learned to keep their experiences, as well as their identities, hidden, in order to ensure their continued survival. (Alexander 2004, Novick 1999, Speigelman 1986, Stein 2009) At the same time, historians and philosophers began to construct a language of the unspeakable when talking about the Holocaust, resulting in a suppressed ability to attempt any understanding of the events or try to come to terms with what had occurred. The Holocaust, like no other event in history, imposed a mixture of collective guilt, shame and horror on the global population, whether directly involved or not, to such an extent that survivors were implicitly asked not to discuss the nightmare but to move on from the past, stifling their ability to work through such horrific, and recent, memories. "We still hear that writers needed a decade or more before they could begin to imagine the horrors of the catastrophe..." (Langer, 4) Although some were able to formulate narratives both during and immediately following their stays in the camps, many were not, leaving the task of 
Holocaust memorializing to future generations. Following the emergence of a culture of silence amongst both survivors and perpetrators, we are left largely, though not entirely, with "memory" in the form of second- or third-hand accounts, that is, representations of representations of representations. Does this "unspeakability" of the Holocaust (discussed in detail in Chapter Five), and the resulting impossibility of historical accuracy, deny historians, authors or filmmakers the opportunity to acquaint future generations with its unspeakability? Or does the fact that Holocaust literature has become an extensive piece of popular culture change the definition of what was previously thought unspeakable?

Through the lens of the master narrative, Chapter Four will address the Holocaust as a subject of film, using both fiction and documentary films as a basis of discussion. With these films, the aim will be to illustrate the master narrative at work within the stories themselves but also within the framework of the film as a visual medium. When viewing a Holocaust film, the audience enters the theater expecting to see iconographic elements which say to them, 'This is a film about the Holocaust.' What are those elements and how does their visual assimilation differ from the assimilated language of written text? How can the act of genocide, as the pinnacle of acts of violence against human beings, be captured on film is such a way that it is both watchable and has the appearance of historical accuracy?

Beyond the visual make up of the Holocaust film, this master narrative suggests guidelines and limitations under which a film can be made with the Holocaust as its subject, a phenomenon that does not exist in relation to other 
historical events. Can a film about genocide in general, or about the Holocaust in particular, be made as a vehicle of entertainment? Does the filmmaker have a responsibility to survivors of the Holocaust to be as historically accurate as possible? What are the consequences when a film changes the parameters of the master narrative or ignores it entirely?

As we move further away from the event itself and witness the deaths of the remaining survivors of the prison camps, what is the future of Holocaust storytelling? If there are limits on who may tell the story and who may not, does the history of the Holocaust become unspeakable in reality rather than as metaphor? 
Chapter Two: Defining the Master Narrative in General Storytelling

At the conclusion of any major historic event, there gradually emerges a master narrative: a set of parameters through which any fiction or nonfiction story construction comes to be filtered. In "Rescreening the Holocaust: The Children's Stories," David Bathrick defines the master narrative ${ }^{3}$ as a matrix which reflects reality in such a way that successful contradiction of it's many facets is rare in either fiction or non-fiction narrative attempts. Although the master narrative may eventually contain erroneous or distorted data, the collection of details as a cohesive whole is largely based on real events, whose underlying veracity is unquestionable. While there is certainly the possibility of attempted deniability against the event as a whole, the basis on which the master narrative is built can ultimately always be proven, even if one or more of the details are found to be false. ${ }^{4}$ This set of constructs

\footnotetext{
3 Bathrick's use of the phrase "master narrative" is specific to the Holocaust. However, the definition herein holds true for any event in history. That is, historians, journalists, novelists, filmmakers and witnesses produce works that construct a fundamental description of historical events simply by writing narratives that are then presented to the public. In his Bradley lecture, Walter Reich describes "Holocaust memory" as "the public's consciousness of the Holocaust in the years since the event." In other words, he uses "Holocaust Memory" as the label for the Holocaust master narrative.

4 The potential for distortion and its danger in contributing to cases of Holocaust denial is addressed in later chapters. However, a case in point is the invention of a concrete number of non-Jewish Holocaust victims. According to Yehuda Bauer, prior to 1979, the number of non-Jewish concentration victims had been recorded as about half a million. Yet, at the national "Days of Remembrance," President Jimmy Carter established the number at five million, a number supplied to him by Simon Wiesenthal. When combined with the 6 million Jewish victims, Carter declared the total victims of the Nazi concentration camps to equal 11 million. This number has now become part of the larger master narrative. The American public (and perhaps others) believe this number to be the truth. However, no documentation exists claiming the discovery of evidence negating the original figure of 500,000. According to Walter Reich, a private conversation between Bauer and Wiesenthal revealed the origin of the number. Wiesenthal had invented it "in order to make the non-Jews feel like they are part of us." See Wiesenthal and Bauer, both quoted in Novick, p.215, and the Reich Bradley Lecture.
} 
is unique to each event and consists of the elements which history will teach the general public about the event and which we will later, as a whole, believe we 'know' about a specific piece of history. What we come to know as the facts of any real historical occurrence is based on the believability of representation of that event as filtered through a subconscious knowledge of the master narrative. This master narrative, in the main, is created organically through a combined and varied number of sources, both objective and subjective.

In The Killing of History, Keith Windschuttle argues that literary theorists, beginning with Derrida, have changed the basic process of documenting history from the search for truth to the creation of metaphor based loosely on incomplete facts arbitrarily chosen on the whims of the particular historian. Factual records are compiled by historians as data on which to base their written histories, but it is not sterile data nor statistics that are presented as history. Windshuttle argues that these compiled facts are, in recent years, presented with the addition of "imaginative reconstructions" meant to fill in data gaps, but which can, and often do, add to public knowledge of the event. ${ }^{5}$ It has become increasingly acceptable among academic historians, he argues, to write 'literary history.' He states that “...one of the most disturbing developments is that some historians have thought it is now permissible to invent some of their 'facts' and to introduce into their works passages that they acknowledge are fiction.” (227) This is not to say that the recording of history is not,

\footnotetext{
${ }^{5}$ Windshuttle is arguing against the practices of historians such as Simon Schama and Hayden White, who believe that it is permissible and necessary for the historian to fill in the gaps where no hard evidence exists. His arguments are for the purity of historical research, however, this thesis only claims that these practices occur, and that they contribute to the creation of the master narrative. The relative merits of the opposing sides of this argument are not germane to the analysis herein.
} 
in itself, narrative reconstruction, but instead that there is a difference between the compilation of historic fact into a cohesive and readable narrative which adheres to the available facts while admitting ignorance in the absence of those facts, and the misrepresentation of fact or narrative invention and literary reconstruction being argued as fact. No longer interested in strictly compiling the historical record for the purposes of pedagogy, the development of inventing literary history stems from the relatively new desire amongst some academics to create works which are financially viable, monetary interest being the goal rather than intellectual integrity. This, as Windschuttle notes, has led more and more supposedly objective historians to interpolate fiction where there is an absence of fact, without announcing to the reader that the work contains sections of fictionalized narrative. He argues that the practice of creating these "imaginative reconstructions" for the purposes of enlivening an otherwise dull subject is worse still. He further explains that proponents of the practices of fictionalizing history justify their positions by arguing "that a story will inevitably be biased, because historians must select only a minute fragment of the events that occurred in the past, and must put these together in their own way to create their own story." (255) Although Windschuttle acknowledges that the documentation of history is inherently selective, he also states that "the practice of selectivity does not justify the resort to fiction." (255) There are many reasons why a historian may select from the myriad facts of an event for his own presentation, including specificity of topic, spatial constraints and even author bias. Hayden White explains that history becomes "a mixture of adequately and inadequately explained events, a congeries of 
established and inferred facts, at once a representation that is an interpretation and an interpretation that passes for an explanation of the whole process mirrored in the narrative" (281). It is partly through these filters that the master narrative comes to be formed since historians are not simply documenters of fact but creators and filters of historical knowledge about any specific event. White calls this type of historical documentation an "explanation" of history rather than an interpretation (281). In other words, the historian is seeking to explain why certain events happened rather than clarifying the order and relevance of the facts for the reader.

The documentation, or explanation, of history is problematic at best, given the inherent complexities of point of view and author bias; and yet, historically, there has been a standard of assumed objectivity. Readers of historical narratives have learned to trust that the underlying facts of the story, if presented as history and not fiction, are as close to a simple and unembellished chronicling of events as is possible given the difficulties of documenting historical data. They are secure in the knowledge that historians, by virtue of their profession, are arbiters of historical accuracy and careful compilers of what will later be passed down to their progeny as concrete knowledge of the event. Students of history have come to rely on the idea that while historical fiction will draw from the details set forth by historians as historical fact, the two narrative constructions are entirely different animals, that although fictional narrative may be based on historical events, history and fiction are not, and should not be, synonymous. How does a historian, in the course of his or her work, write an accurate and unadorned account of history without resorting to fictionalizing the event, 
especially when that event is associated with human trauma? Can emotionally charged testimony be called evidence? Can trauma be related in such a way that it can be considered objective and unembellished?

While it is certainly preferable that a historian not bring his own feelings or biases into the presentation of history, there is an additional assumption among many traditional academic historians that fact can and should be presented without relating the emotion of those entangled in the history they are recording, without accounting for the human psyche as it is involved in experiencing history. Although this is certainly possible in the case of the mundane, it cannot be so in the case of the extraordinary. If, on September 11, 2001, New Yorkers had simply gone about their lives as on any ordinary day, history could have recorded that day without detailing the individual emotional experience, the ideal being that there is no room for emotion in the documentation of historical fact. However, the facts in that case involve not only the destruction of the Twin Towers by hijacked aircraft, but the massive loss of human life as a result, and those left behind experienced terror, loss, grief and horror. Some historians may, in fact, attempt to record the 9/11 events in New York as sterile and not involving human beings as individuals but as statistics; however, when the victims and survivors are available to add detail and thereby create a subjective narrative rather than an objective study, such a sterile history will not be looked to as the definitive source by which we remember the event. Although government statistics may record that a specific number of people died and a finite amount of property was destroyed, statistics will likely refrain from including the narrative of the 
woman standing on the street wearing a sandwich board bearing her fiancé's face and asking passersby if they have seen him. Survivors of tragedy invariably seek to know the whys involved in history in order to identify cause and assess blame in an attempt to come to terms with events that otherwise seem senseless. Human beings do not want to believe that wanton tragedy occurs; there must be a reason behind all acts of cruelty, terrorism, murder, and other such horrific phenomena. (Tilly, 447) It is the existence of the why factor that changes the documentation of trauma in history from emotionless fact to chronicles of the emotional details of individual tragedy and thereby creates narratives of human trauma as people share their own stories in an effort to understand the larger picture.

The master narrative, then, is constructed not just from statistics and other data arranged in a logical format by which we grow to understand a tragic historical event, but also from the anecdotal detailing of individual experience. Statisticians have reported the number of lives lost in the 9/11 attacks based on the payroll records and other hard evidence available at the time, so we know that 2966 people were killed in the attacks. ${ }^{6}$ We know that four planes were hijacked and that two were flown into the Twin Towers, one into the Pentagon and one into the Pennsylvania countryside. We know that desperate people jumped to their deaths to escape the fires. However, this is not the whole story or even the majority of the story of $9 / 11$. It is, however, something that everyone can agree upon as fact. Government archives, though dry records of statistical data, are seen as reliable contributions to our knowledge of

\footnotetext{
${ }^{6}$ This was the initial report, however, this number is in dispute.
} 
history, though they can be lacking in detail and are certainly lacking in the human element. The Nazi regime kept records of their actions, both accurate and inaccurate, which has been helpful in the reconstruction of the Holocaust as history, ${ }^{7}$ but such documentation, especially from the perpetrator's perspective, is limited to the facts and figures that were necessary to running the ghettos and camps efficiently and cannot be taken as truth but can only be seen as fact and then only if verified by additional sources, given the Nazi propensity to convolute the reality of life for Jews under their rule. Fact, though helpful in recreating events, can only be considered part of the elements that make up the whole truth of an event. Similarly, newspaper accounts, though less objective than statistical data, are often perceived by the public as faithful narratives of events as they unfold and therefore add substantially to the master narrative, although it should be noted that there is never a guarantee that a newspaper account will, in any way, be objective. Even the most subjective of writings, such as personal diaries or journals and letters written to family or friends, can arbitrarily contribute to the master narrative in that there are no guidelines for what is included, only that the public as a whole accept the narrative as part of the overall matrix. It is, therefore, entirely possible that the master narrative, what we know about history, can be, and often is, made up of personal narrative as well as historical data. It can, in fact, include myths and legends often passed on as truth.

\footnotetext{
${ }^{7}$ While accurate records help historians to recreate the details of an event, inaccurate records can also supply useful information. Inaccuracies, of course, first tell us that the Nazi regime was not above duplicity and deceit. However, more interestingly, the deliberate inaccuracies in such records sheds light on the items which the Nazis felt were important to hide from the rest of the world.
} 
Windschuttle argues that exposing "the reality behind some of the legends of our culture is one of the legitimate tasks of the historian. But this role can only be performed by historians who have some faith in the ability of the profession to get to the truth by shaking off the ideological garb in which an individual or an event has been previously clothed, that is, by seeing it objectively."(256) The very fact that he states the necessity of exposing legend as being part of the profession of the historian illustrates the frequency with which legend makes its way into the annals of history. If, however, as Windschuttle explains, we should be interested in seeking the truth in documenting history, we must acknowledge that there should be a separate and distinct set of rules involved in seeking truth as it pertains to the documentation of traumatic history, which, by its very nature, cannot be presented as fact separated from emotional experience. Windshuttle does not make a distinction between traumatic history and non-traumatic history ${ }^{8}$, stating that all history should be removed from the personal agenda and influence of historians and should instead be documented without embellishment. However, ignoring individual history as a part of the larger event only seeks to remove humans from human history, and in the midst of trauma, history and individual experience cannot be separated.

\footnotetext{
${ }^{8}$ Cathy Caruth explains the difference between traumatic and non-traumatic history. Non-traumatic history is the history of the mundane. If the President of the United States gives a State of the Union address, it is considered a piece of history the moment he concludes. No trauma is involved. However, an event such as $9 / 11$ is a piece of traumatic history as it involves the deaths and suffering of living beings who can relate their stories to others and, potentially color their memories and make them less objective. She claims that trauma victims "carry an impossible history within them, or they become themselves the symptom of a history that they cannot entirely possess." See Caruth, 1995.
} 
Although historians have a perceived obligation to expunge myth and legend from the factual, historical master narrative, in the documentation of traumatic history, as with the Holocaust, myth and legend have become enmeshed in the overall matrix as a result of the effects of trauma on memory. Once either of these types of 'history' or indeed, personal individual experience, become accepted by laypeople as unbiased and unemotional fact, due to its presentation as history and therefore as part of the master narrative and truth about the event, it is difficult to change or replace the matrix. It is this matrix, then, on which we build future fictional as well as factual accounts. Although fictional representations of history have the freedom to invent narrative where facts are lacking or where the master narrative fails to provide answers, factual accounts also become mired in the master narrative due to the fact that even if the account deviates from the master narrative, it must at least acknowledge that from which it is deviating in order to make the reader understand how a particular event is being treated.

Therefore, as fictions may be written on the basis of how a historical master narrative is understood by the writer, that master narrative can, itself, be based on fiction. Additionally, the elements of the master narrative are independent of the form of storytelling. That is, stories that make use of the master narrative and abide by its contents are further guided by the rules of story structure, grammar and so forth, something that can limit the scope and focus of the master narrative to a single element, i.e., a particular person, or day or moment in time. Since writers of historical fiction draw from the master narrative of a given event in order to create a story based 
on historical fact, the master narrative then guides the writer intent on documenting history, regardless of the fictional nature of the resulting story, although the 'facts' living in public consciousness are not necessarily devoid of personal experience or politicking. Further, since most writers of historical fiction are not themselves historians by profession, and thereby given to fact-checking or an adherence to historical truth, the matrix may be accepted by the writer of fiction as fact without reservation, nor is he necessarily bound by the limits of history, even assuming that he does his homework and researches the underlying facts involved in the story he wants to tell. To paraphrase Mark Twain, 'the difference between history and fiction is that fiction has to make sense.' Fiction must be a plausible representation of the truth, whether the reader knows the truth or not. Therefore, where the traditional historian may feel constrained by the facts of history in all their chaos, the writer of historical fiction may bend, stretch or fabricate the 'facts' in order to produce plausibility. Roland Barthes calls this 'the reality effect,' that is to say, the phenomenon wherein real history is complemented by "insignificant notations," details that give the appearance of reality but which are, in and of themselves, only representative of the endless scenarios possible in the course of history, and which cannot be verified nor discounted. (16) To complicate matters further, the popularity of historical novels can, in fact, add to the master narrative, thereby creating the belief that narrative fiction is the presentation of fact in a lyrical format, adding more 'insignificant notations' to the master narrative of the event. 
While all master narratives of historical events result in a continuum of

accuracy ${ }^{9}$, the Holocaust, unlike other events, has a system of watchdogs in the form

of survivors and their descendants, who are quick to criticize elements which may

stray too far from the accepted master narrative or make the opposing ends of the

continuum too disparate. In this sense, there is an element of attempted design of the

Holocaust master narrative; ${ }^{10}$ however, this is mainly in the form of desired

restrictions as a result of a perceived trivialization or commodification of the

Holocaust. $^{11}$

It is because of the impossibility of a single or group of architects in

constructing historical reality and subsequent persistence of legend masquerading as

fact that this thesis seeks to document the master narrative of the Holocaust generally, and more specifically as it pertains to cinematic representation of the Jewish experience during WWII.

\footnotetext{
${ }^{9}$ Documentation at the start of any historical event will continue to grow and take on new elements as more facts are uncovered, and after these facts have been interpreted and understood. While the individual adjoining versions may, at any given point in the timeline, closely resemble each other, the two ends may not, thereby creating the illusion that the story has changed drastically, when in fact, it has been systematically changed to match the analyzed data over a long period of time. In relation to the master narrative, these changes may also include subjective as well as objective data.

${ }^{10}$ This idea certainly allows for the existence of Holocaust deniers, however, as with other elements of this particular master narrative, the Holocaust is unique in this. Those who deny the Holocaust are far outnumbered by the voices of the survivors, as well as the empirical evidence available. Deniers of the Holocaust frequently use the elements of the master narrative against itself in an effort to disprove the event without giving credence to documented data collection. The interpretation and acceptance or denial of individual elements of the Holocaust does not, however, provide evidence that the Holocaust didn't occur, nor would it for any other historical event. Holocaust denial appears to rest solely on the convictions and desires of the deniers rather than the accumulation of empirical evidence.

${ }^{11}$ This is not simply the correction of inaccuracies in the historical record. Writers such as Wiesel, Lanzmann, Wiesenthal and others have attempted to guide the history of Holocaust survival in that they have been very vocal about what should be and should not be said with regard to Jewish victimology as it pertains to the Holocaust. These restrictions include the acceptability of entertainment media to disseminate Holocaust narratives, the rightness of non-Jewish historians as authors recording the Holocaust and so forth.
} 
However, it will at first be useful to demonstrate the existence of the master narrative for an unrelated event in American history to act as a starting point from which to understand the use of a particular matrix in storytelling. An example of such a master narrative is evident in the formation of the Constitution of the United States of America.

As Americans, we know, that is, we understand the master narrative to say, that the Constitution was created in Philadelphia by a group of men engaged in political debate not only over the basis of American law but over the exact language to be used in framing those laws, and what that language would mean for the governance of the people of the newly formed United States. We know that Thomas Jefferson was instrumental in advocating the separation of church and state in government affairs and that Alexander Hamilton stood strongly in favor of federal rights over state rights. We also know that, once written, the document was considered by many to be inadequate, thereby necessitating the addition of the Bill of Rights. Although this is by no means a comprehensive accounting of the Constitution master narrative, it is enough to use for the purposes of illustration.

These elements, when taken together, and in conjunction with those I have left out in the interest of brevity, form the groundwork on which we base any narrative of the framing of the constitution. When a writer begins the documentation of American history, he knows that these elements must be present or what he is writing will be seen as deliberately treating the master narrative as false, inadequate or untrustworthy, or that the narrative he has written is a work of alternate reality. In the first case, the 
writer must address, or at least understand, that his work disputes those elements believed to be fact and provide evidence that his narrative is the more accurate. If the narrative is of the second type, while it need not overtly acknowledge the master narrative, the writer must at least be sensible that the deviation will invite comparison, if only to acknowledge that the master narrative is that from which the writer has deviated. In both instances, the master narrative is the standard against which a historical narrative is written. The fictional historical narrative must at least be closely related to the facts of the event. That is not to say that fictional narrative can, nor should be, mere statements of fact, but instead are a particular ordering of facts into a coherent whole based on the goal of the writer in question. If the author's goal is to highlight a particular day, for instance, the day on which the Constitution was signed, he would structure the facts accordingly, in such a way that the focus would be on a single moment in time rather than on the events which, though still part of the history of the Constitution, would not necessarily have anything to do with this particular piece of history. At the same time, the author could not deny that other elements exist, only that they are less important to his narrative focus.

However, the master narrative also acts as a guide by which readers of literature and viewers of film understand works of history. The master narrative allows the reader/viewer to match this set of historic guidelines with the work being read and know that this is a work about a specific event in history. If, when viewing a film about the framing of the Constitution, the audience can identify that Alexander Hamilton and Thomas Jefferson are playing their prescribed narrative roles, 
suspension of disbelief is preserved, regardless of how many of the details are invented, or indeed left out, by the writers. In fact, as Barthes explains, the details surrounding the facts are what lend the feeling of truth to the narrative. The details then become significant in that they convey the truth of the object being described, (16) in this case, Alexander Hamilton and Thomas Jefferson.

Readers and film-goers have also come to rely on an additional element in their understanding of history, that of the time machine fantasy, which takes two forms. The first is blatant in that the characters in the film are transported into another reality. The second, and more common, is subtle and is a device used to bring the audience into the filmic experience as it occurs in a different period than his own. This fantasy employs the idea that the ultimate goal of fictional narrative is to create the illusion that we are experiencing the truth of history, either through written description or visual narrative. Historical novels have relied on this fantasy in written narrative, to make the story seem more immediate, and therefore real. The time machine fantasy is also assumed to be at work in viewing a historical film. Without the ability to be mentally transported into the past, the visual narrative does not work. If we are constantly reminded that what we are seeing in the cinema is the result of the work of a cameraman who was sitting in our position and who captured the action we are currently seeing as it was performed by actors, then the film fails to do what it's charged with doing, that is, to transport us into the midst of the event we are witnessing. Therefore, we don't hear the director directing an actor to pretend he is starving or watch the makeup being applied to a rosy complexion in order to create the 
illusion of illness. This set of illusions that makes up the time machine fantasy leads to the belief that we, as receivers of the narrative, know the truth about history, whatever that truth might entail, following completion of a fictional representation. But like all historical fiction,

The cinema holds out the historian's dream of complete and unmediated access to the past at the same time that its efforts reveal the artifice required to hold such a dream in place. The cinema offers a quintessentially postmodern position, oscillating between the desire for plentitude, for total transparency and knowledge of the past, and the impossibility of ever achieving that goal. (Finke, 6)

Although both novelization and film as representatives of history claim to expose reality, there is an underlying understanding that what we are reading or seeing is a fictional construct which requires the "suspension of disbelief" from its audience for success. Storytelling of all kinds, regardless of the medium, is created to envelop the listener. "It is that willing suspension of disbelief for the moment, which constitutes poetic faith." ${ }^{12}$ Nowhere is more poetic faith necessary than in the viewing of historical film. The filmmakers reconstruct the details of life in a specific period in history in order to allow us to be transported by the time machine, that is, to participate in the representation so thoroughly that we might believe we have experienced it firsthand and temporarily cease to recognize that we are sitting in a movie theater in our hometowns rather than following the founding fathers around the streets of Philadelphia.

However, if the film were to make Hamilton and Jefferson dueling starship captains or make them agree on everything so that debate wasn't necessary, the

\footnotetext{
${ }^{12}$ Samuel Taylor Coleridge.
} 
audience would instantly recognize the deviation and, barring the possibility that the narrative is acting as a metaphor, the 'insignificant notations' would signify that this is not a truthful representation of historical reality. Our time machine would then become a transporter to another dimension, one with which we are not familiar. Such changes to the narrative of Constitution formation would no longer be recognizable as components of known, and accepted, history but would, instead, transport the narrative firmly into the realm of fiction or even fantasy, without the historical element. Without an adherence to the master narrative as an underlying framework, with at least some of its descriptive details, the filmmaker is no longer representing history. While the viewer may be willing to accept that the account is fiction, he is rarely willing to accept changes to the master narrative which render it unrecognizable as the event in question.

The writer is then both aided and burdened by the general public's knowledge of the master narrative, or rather, the public inhabits the history that he or she knows and the writer must work within the framework of this house of history in order to be acceptable to the reader but has the freedom to remodel, within reason. That is, film, with the master narrative as a guide, tells the viewer what he already knows and accepts as part of his mastery of history. The writer is aided by the fact that the characters and settings will be known and easily recognized as belonging to a particular event in history and only that event, and he, therefore, need not lay down a backstory chronicling how he arrived at the novel's locus nor account for why he has begun his story at any particular point in time during the event's occurrence. He need 
only give clues as to where and when we are and we, as viewers, subconsciously draw on the particulars of the master narrative to assist us in locating ourselves within the story. If, however, as in the above example, we find ourselves overhearing a debate on Article I of the Constitution in a fruit market on the streets of Calcutta, we would be lost and would require eventual explanation as to how we ended up here and not in Philadelphia. The burden subsists in the writer's inability to deviate from the master narrative in any substantial way, to tear down the history and build a new one in its place. Though Bathrick's reflected reality gives the writer something on which to base his story construction, that construction must accurately reflect salient points in the reality on which it is based in order to garner reader approval, regardless of whether these points are factual. The truth of the story is determined by the reader, depending on his knowledge of the underlying master narrative, further complicating the possibility of locating the truth in relation to history.

Although the above is largely in relation to the written text, it is equally applicable to the cinematic documentation of historical fiction. However, the nature of both film and film audiences add other, more particular, layers to the master narrative specific to cinema. As a visual medium, film cannot rely on vague description or flowery language to distill a scene in the viewer's mind. The filmic storyteller must show the audience meaning. The very fact that film is visual, and therefore appears to be representational of reality in a way that written text is not, is much more evocative in terms of the master narrative and necessary mise-en-scene. ${ }^{13}$

${ }^{13}$ Mise-en-scene can be described as the visual details and composition of the scenes in which the production is set, the elements that make the story come alive. This includes the props, such as the 
In the world of cinematic representation, it is not enough to name the characters Hamilton and Jefferson and let the audience fill in the details of their appearance nor to label the setting 1784 Philadelphia, the audience must see that the actors resemble Hamilton and Jefferson. They must see horse-drawn carriages rather than cars. The characters must wear period clothing and speak in the expected dialect. The audience must be convinced that the world they are viewing on screen is the world it is pretending to be. This visual layering is not so much a cinematic replacement of the master narrative as a refinement of it. The historical film must wear the window dressing of the history in which it's set.

Important in all film, as a component of visual narrative, is mise-en-scene; the details within the frame which establish time and place, and which provide clues as to how the audience should read the scene. Similar to the genre film, wherein the audience enters the theater knowing, at least marginally, which details must be present, or indeed absent, in order to make what they are seeing a film of a particular genre, the master narrative creates a subconsciously understood list of elements which the audience expects to see in a film made about a historical event. This invoking of the past through visual language is essential in order to create a believable film narrative. In other words, the master narrative establishes the event's individual language and film displays that language visually for an audience who speaks or, at the very least, understands that language and its dialects. In "The Reel Joan of Arc",

larger details like cars, horses, airplanes and buildings, as well as the minutiae like books, coffee cups, and street litter; actors and their costumes, which must represent the story being told; the sets in a larger sense, such as the interior of The White House or the Kingdom of Oz; and even the lighting, as in the strip club scene in The Graduate. There is some debate as to whether mise-en-scene should also include the camera's position and movement, however, this debate is not germane to the current discussion. 
Robert A. Rosenstone reminds us that "filmmakers encode messages not just in the characters or story, but in the very visual language in which they choose to speak of the past." (72) The messages left within the film for the viewer to discover are visual specters based on the master narrative, however, they are often more subtle than the descriptive messages left by an author of written text. It is not simply the medium of representation that is different, but what it represents as well.

Keith Windschuttle argues that the historian seeks to find truth. (251-278) It has also been argued that filmmakers seek to present a type of truth, that is, the historical filmmaker often believes himself to be contributing to the master narrative, or public knowledge, of history. We must question whether film can ever convey such a truth, and, if it can, how is truth being defined? Nietzsche posited that a transcendentally clear notion of truth cannot exist because human beings, though intelligent, do not have the capacity to create the necessary linguistic signifiers required to convey singularity of meaning, since each word or picture, though meaningful to the user, will, due to personal experience, history and language, have a different meaning for the receiver. Therefore, all we can hope for is to convey meaning through the use of metaphor. (878) Film becomes a way of conveying a form of truth that is not wholly based on facts, but makes use of visual language to create a viewable metaphor derived from the master narrative.

"The basic element, the camera, is a greedy mechanism which must show in more precise details - arrangements of furniture, the ways tools are handled, stances or gestures, the exact locations of peasants in a landscape - than historical research could 
ever fully provide." (Rosenstone, 72) Since the medium of film exposes the historical landscape not simply in the center of the frame but through the details to its very edges, the audience registers the historical traces of the master narrative both consciously, as in the dress and accent of the characters, and subconsciously, as in the distant landscape or ambient sound of the scene. "Both written history and films invoke the authenticity (or reality) that comes from using those traces, that documentary evidence we call 'facts' and then go on to employ a literary or filmic vocabulary to create "History"' (Rosenstone, 73) Although film, as a medium of entertainment more than education, will never recite facts in the dry manner desired in historical textbooks, it "must somehow engage the discourse of history, the already existing body of writing, arguments, debates, memories, images, moral positions, and data surrounding the topic with which it deals." (Rosenstone, 76) In other words, film must acknowledge and engage the master narrative in a dialogue carried out through cinematic language. Without engagement on some level, the film may be considered entirely unrelated or unfaithful to the knowledge of the event that it seeks to elucidate. Within the framework of both history and film language and dialectic, the following chapter documents the singularity of the Holocaust master narrative and its limitations on narrative organization as well as illustrating the incongruities of the master narrative as it sets out guidelines for the recitation of traumatic events. Subsequent chapters will address the Holocaust master narrative as it is used in film and how it creates a rhetorical environment through which the Holocaust is discussed. 
Chapter Three: A Documentation of the Master Narrative Specific to the Holocaust as a Historic and Singular Event

The Holocaust master narrative is unlike the narratives of any other historical event, including genocidal events, in that the tropes we recognize as being ingrained in the public consciousness as elements of the master narrative are supplemented by a set of rules by which transmission of Holocaust memory, history and knowledge may take place, according to those who survived it. These rules, though not codified in the sense that laws exist in any country governing the relaying of Holocaust history, are codified in the sense that they are stated and restated in the multitude of literature on the subject, rules that have seemed to the survivors and their descendants to be obvious, but which are not necessarily so to those outside the Jewish faith. This governing layer then becomes part of the master narrative while at the same time complicating the narrative by attempting to suppress it. ${ }^{14}$

As discussed in the previous chapter, the master narrative accumulates haphazardly and without forethought, but begins by recognizing a set of assumptions made by the public at large based on what they believe they know about a given historical event. What then are these public assumptions about the Holocaust? It is

\footnotetext{
${ }^{14}$ Indeed, the research for this thesis was made all the more difficult in that there is a near impossibility of separating the core narrative from the imposed limitations on memory transfer and documentation within the available literature. The self-imposed rules governing documentation appear to be nearly universal in Holocaust study. Therefore the debate over authenticity is central. Some believe that in order to accurately convey traumatic memory, one must have experienced it, while others say that the experience of trauma makes objective recording of history impossible. The accounts will certainly differ but this doesn't necessarily make any of them untrue. Rather, they can be seen as differing vantage points of the same event.
} 
perhaps useful to begin by defining what we mean by "The Holocaust ${ }^{15}$ ". By this particular phrase, history means to denote the destruction of European Jewry at the hands of Nazi Germany, and specifically Hitler, during the period of 1933-1945, imprecisely imagined to be World War II. Americans were introduced to the aftermath of this destruction through popular media. "Camera teams filmed the horrors that remained of the concentration camps after the liberation-piles of bodies, crematoria, stacks of personal possessions_-and the skeletal survivors." (Doneson, American Film 7) These elements of the Holocaust then became the foundation on which Americans began building their Holocaust knowledge. It is not particularly surprising then, that future understanding of the Holocaust would come from cinematic representation given that American initiation into the reality of the camps, though limited, was delivered in a similar medium. However, Doneson also points out that the result is not a universally recognizable Holocaust, one whose history is the same in every country and wherein the United States acknowledges its actual role in the destruction, but instead, it Americanizes the Holocaust into a commodity that is easily digestible by the American public.

The matter most closely connecting America to the Holocaust was its refusal to allow Jewish refugees entry into the United States - in retrospect, a tragic decision for the Jews...Ironically, the most successful films utilize American

\footnotetext{
${ }^{15}$ For the purposes of this thesis, the term Holocaust is understood to be particular to the discourse on WWII taking place in non-Jewish America on the subject of the genocide of the European Jews and does not mean to argue that this term is universal. There has been some controversy as to the use of the term due to its origins in Greek etymology as an animal sacrifice to the gods wherein a whole (holos) animal is burnt (kaustos). While this marginally defines the burning of corpses in the ovens of the concentration camps, debate stems from the argument that the Nazis had no such sacrifice in mind and were not paying homage to God but were ridding themselves of those they considered to be the enemy. The term's original etymology also implies that Jews are not human, which, although an argument made by Nazis during the genocide, is not in any way implied by the use of the term herein.
} 
symbols and language to convey an American perception of the (European) Holocaust. In effect, we are talking about the Americanization of the Holocaust... The cumulative effect of a series of films on the Holocaust has been to create a lasting image of the event in the mass mind. Since these films tend to reflect contemporary trends, they help to make the Holocaust meaningful to an audience for whom the Final Solution was a foreign event. At the same time, they strive to place the Holocaust in its proper historical context — as the attempted genocide of European Jewry by the Nazis. (American Film 910)

Doneson's book focuses on the ways in which film has helped to change the American conception of Jewish history. The Holocaust Jew has become separated from all other Jewry in both physical and temporal location and, removed from the context of the overall destruction of European Jewry, he has been given a place of special honor in the American psyche as the archetype of human suffering. While this is certainly an important and influential element of the Holocaust master narrative, it does not define the entire matrix. At this point, further discussion of archetypes within the Holocaust master narrative is necessary.

Bathrick's definition of the master narrative postulates that future cinematic representations of the Jewish experience in WWII can't help but utilize the narrative matrix set forth by the 1978 television mini-series Holocaust ${ }^{16}$ and the 1993 film, Schindler's List. ${ }^{17}$ Therefore, it seems useful to begin the search for Holocaust archetypes in these productions. However, his argument also relies heavily on the

\footnotetext{
${ }^{16}$ Although I am primarily focusing on the master narrative as it pertains to film, the matrix is a basis of knowledge which is instinctively used in storytelling as a whole and therefore includes television.

17 Many Holocaust scholars refer to these two productions as germinating the seeds of what would later become a fully formed master narrative of the Holocaust, including David Bathrick, Joshua Hirsch, Judith Doneson, Yosefa Loshitsky, Omer Bartov, and Barbie Zelizer. However, with the exception of Bathrick, emphasis is given to Schindler's List.
} 
documentary Shoah, which he offers as a counterbalance to the "Hollywood paradigm" utilized in the two above-mentioned films and which, itself, augments the master narrative.

Since Holocaust is the earliest of the three, and the one which holds the distinction of returning the Holocaust to the forefront of American historical memory, this mini-series may be regarded as the codifier of the Holocaust master narrative, with Schindler's List acting as both confirmation of the matrix and a lightening rod for frustration with the non-cinematic community for Hollywood-izing, and therefore commodifying, genocide. ${ }^{18}$ Holocaust was also "among the first American popular films to focus on the Final Solution as a specifically Jewish event" (Doneson American Film 149) rather than as a byproduct of a war which resulted in 60 million deaths worldwide or as a genocide that included not only Jews but gypsies, homosexuals, the mentally retarded and political prisoners. Holocaust focused on Nazi aggression against European Jewry as both a means and an end to global dominance. However, as mentioned above, Holocaust, as with Judgment at Nuremberg $^{19}$, debuted into an America that needed to understand the Holocaust not in terms of the victims, but in terms of itself, in that Americans were more receptive to

\footnotetext{
18 There are numerous examples of the construction of the master narrative of Holocaust victimhood, survivorship and witnessing much earlier in literature with the writings of Primo Levi and Elie Wiesel, as well as others, but these had limited readership in America at the time they were published. These writings will be discussed further later in this thesis as they pertain to the transfer of the elements of the master narrative from literature to film and to the taboo against Holocaust representation.

19 Judgment at Nuremberg was the first American film to fictionalize events of the Holocaust or its aftermath. It also created a bridge between what had been shown in newsreels at the time of liberation and the fictionalized account of the trials at Nuremberg by using actual news footage in the production. However, since the film was not released until 1961, the American public had been separated from the events of the Holocaust by 16 years and therefore much of the memories of WWII had been lost for 1960s America.
} 
productions that helped them understand their own participation in the Holocaust. Therefore, Holocaust gives a somewhat distanced view of the event for an audience that did not participate in it nor fully understand it. By the time the mini-series aired, it had been tailored to discuss an Americanized Holocaust. "The viewer had to be given the impression that Holocaust pertain[ed] to him..." (Doneson American Film 150-151). From the earliest scenes of Holocaust, we can see the American influence. ${ }^{20}$ Eric Dorf, who is meant to portray the coldly calculating designer of the Final Solution, states, during his job interview, “I haven’t worn a uniform since I was in the Boy Scouts." (Holocaust, 1978) While the German version of the Boy Scouts existed in the form of the Pfadfinderen, this particular phrase would not have endeared him to the Hitler's Reich, since, fearing competition, Hitler had abolished this and all other scouting groups in 1933, two years prior to the timeframe depicted in the miniseries. However, it was a phrase which would help the American viewing public identify themselves within the story being told. Additionally, Holocaust was not made for Jewish American audiences, who presumably never allowed themselves to forget the Holocaust, but for non-Jewish American audiences, who might need to be reminded of a horrific incident in human history. The violence is watered-down and unrealistic, largely taking place off-screen and thereby wholesome enough for the 1978 television viewer who, we must assume, was only willing to get small doses of the reality of the Holocaust and whose exposure to television violence and traumatic

\footnotetext{
${ }^{20}$ Herein what is meant by master narrative is an American master narrative of the European Holocaust. Of necessity, each country or culture around the world will have a different idea of any historical event. Just as the experience and documentation of the 9/11 attacks are different from Americans than they are for Iraqis or Afghans, the holocaust was both experienced and recorded differently in individual cultures.
} 
reality was limited by the practices of the time. In addition, the miniseries takes the interesting stance of adding the Christian element. Therefore, while the miniseries acknowledges that the Catholic Church played a role in sponsoring wholesale antiSemitism, it also performs religious sleight-of-hand. While listening to a radio address rallying the people of Berlin to rise up against "the demon Jew," Rudy Weiss shouts "Go to Hell!" a place which does not exist in Judaism, at least, not in the sense that it does in Christianity and certainly not by that term. But again, it helps the largely Christian American audience identify with the events taking place. The WWII master narrative, therefore, is an Americanized and Christianized version of historical truth regardless of the fact the Holocaust was directed at European Jewry and America was very late in joining the war against Hitler. Once the ground is prepared for American acceptance of the Holocaust as an event which can, and should, induce sympathy for the plight of the European Jew, the story begins to add elements of the narrative, most of which still operate as the cloth from which contemporary Holocaust and Holocaust-related films are cut.

Holocaust approaches the subject of the destruction of European Jewry by beginning with the war as a whole, that is, the backdrop against which the Holocaust takes place is WWII Europe, however, it also begins with a hint that anti-Semitism is a real threat to peace, although war has not yet been declared. Karl and Inga's wedding hosts a tense side discussion between the bride's father, brother, and a family friend, Heinz Müller, regarding the wisdom of Inga marrying a Jew. Müller suggests that "the Party" may soon be restricting such marriages, and implies that this one may not 
only be considered null and void as a result, but could cause problems for the Helms family in the future. In 1978 America, there may or may not have been cultural knowledge that "the Party' in question was the Nazi Party. ${ }^{21}$ The Nazis in uniform are outside the wedding, sitting at an outdoor table, drinking beer. Similarly, the Nazis in Schindler's List are first introduced to the audience as a group of men enjoying the liberties of a night at a cabaret. Neither film presents the Nazis as any particular menace initially. In fact, Schindler's List begins with a title card that states "September 1939, the German forces defeated the Polish Army in two weeks" (Schindler's List, 1993) followed by statements that the Jews of Poland are being moved to the city of Warsaw and must register all members of their families. No mention is made of the fact that it is the Nazi party that is requiring the registration of the Jews of Poland. The war is not the focus in this film; the focus is on the treatment and reaction of the Jews but even that is secondary to the transformation of Oskar Schindler from member of the Nazi party in good standing to rogue savior of doomed Jews.

As these films progress, cruelty begins to emerge and the Nazi archetype within the master narrative becomes visible. This perpetrator is not the stereotype of a villain from classic Hollywood. This Nazi is the cold and calculating average man whose pleasure is derived from the cruelty he inflicts, but at the same time, he has a softer side. No longer the outwardly monstrous, ranting, hate monger of legend,

\footnotetext{
${ }^{21}$ Holocaust was not produced in response to an audience desire for more information on the Holocaust as an event. Rather, the mini-series was born from the commercial success of Roots the year before. Since the country had taken a new interest in ethnic concerns, the time seemed appropriate to produce a similar history of the enslavement of Jews in Europe. (See Judith Doneson's The Holocaust in American Film, page 145.)
} 
Holocaust's Eric Dorf is portrayed as a man who needs a job and joins the only outfit hiring in the depressed German economy, the Nazi party. He is the representation of Hannah Arendt's "banality of evil" (Eichmann), a man whose crime is that he's doing his job, and doing it well. Lance Morrow describes Dorf as "a prissily murderous family man and SS officer around whom nearly all the horrific deeds of genocide are crowded" (Morrow, Holocaust, online). Dorf is a fictional character partly based on Otto Ohlendorf, and partly on Adolf Eichmann, and who polarizes the film into a "battle between the German and the Jew, and in so doing, omits most of Western Europe from consideration" (Doneson, American Film 159) in order to focus the American audience's response to the film. He is not, however, merely the man following orders; Dorf is the creator of many of the measures taken in the Final Solution, though he is given three potential motivations for his actions in the event that debate should arise over his role in the genocide. First, General Heydrich immediately alerts the audience to the list of reasons Hitler and the Nazis gave for the "extermination" of the Jews. He cites racial purity as foremost, followed by the infiltration of Jewish businessmen into the economy. The idea that Jewish workers are taking German jobs is seen as justification before the audience is ever even introduced to what this will mean or how widespread anti-Semitism will become. Second, throughout the mini-series, Dorf remains in a subordinate position. When Heydrich is killed in a car bombing, Dorf does not take his position. Instead, someone more powerful and seemingly more vicious takes Heydrich's place, giving Dorf the future ability to claim that he is just doing his job, should he need to do so. However, there 
is a third, more disturbing, aspect to his character as a good German and a man who always follows orders. Late in the mini-series, when Dorf appears to question his own involvement in the Final Solution and confesses the nature of the annihilation of the Jews to his wife, she is unsympathetic to either her husband or the victims. Instead, she believes his job should take precedence over any sentimentality regarding the Jews and berates him for his weakness. This triple layer of protection against blame solidifies the German-as-victim element of the master narrative initiated in Judgment at Nuremberg, while at the same time the audience begins to associate the Final Solution with Dorf-as-architect rather than as the result of a well thought out plan by the Nazi regime. ${ }^{22}$ This simplifies the issue for the American audience; however, it creates a new debate amongst genocide scholars in general, and Holocaust scholars in particular, that of the Hollywood factor.

David Bathrick brings into focus the "Hollywood question," that is, the tools used by Hollywood filmmakers to make a film a pecuniary success regardless of whether these additional or subtracted elements detract from the truthfulness or validity of the narrative with regard to the event itself. He questions “... whether the Hollywood paradigm is capable of grasping such an event as the Holocaust."

\footnotetext{
${ }^{22}$ Nazi planning and execution of the Final Solution has been well documented by scholars such as Christopher Browning, Raul Hilberg, Aly Gotz and Martin Gilbert. The mass killings, torture and enslavement of European Jewry was very sophisticated and thought out. The gas chambers were invented for the sole purpose of exterminating human beings; Zyklon-B was used instead of causing the soldiers the trauma of mass shootings; the ovens and oven rooms were built specifically to dispose of the bodies is an efficient manner. However, this network of machinery and people were not in any way the decisions nor suggestions of a single, low-level bureaucrat in the Nazi regime as the mini-series seems to suggest.. Rather, the Final Solution was a system of death instruments organized at the highest levels.
} 
(Bathrick, Rescreening 44) In this case, the "Hollywood paradigm"23 flattens

out the Nazi regime, taking it from being a vast and malevolent network which worked in a coordinated effort to perpetrate the Holocaust and, instead, presents the audience with the archetypal villain, who, rather than being an anonymous and amorphous group, is a person with a specific identity who acts as a focal point for all blame. He is an individual who, while he declares that "We're not monsters" in one scene, in another states that "Jews have always been fair game" as justification for his increased restrictions on, and brutality against, the Jewish people, and in another calls both Jews and Russians "subhuman" and "born to slavery." (Holocaust, 1978)

In Schindler's List, the Hollywood factor supplies the audience with a marginally prettier ${ }^{24}$ version of Amon Goeth as the personification of evil. Since his character is that of a historical figure rather than a characterization based on the splicing of more than one person into a screen personification, Ralph Fiennes is embodied with the traits of the real Amon Goeth. He is cruel, his punishments arbitrary, his psyche on the brink of psychosis. But his is not the tame, watered-down

\footnotetext{
${ }^{23}$ The Hollywood paradigm is such that films are created with an inherently understood formula. This formula consists of the idea that there must be a clear beginning, middle and end. There is a causal chain of action which carries the action forward, such as the successive events that eventually lead to Mr. and Mrs. Weiss being taken to Auschwitz. There must be a clear protagonist and antagonist. In Holocaust, the protagonists change depending on the scene, however as a group, they are the Weiss family. The antagonists are certainly the Nazis in a larger sense, but specifically the role has been given to Eric Dorf as the quintessential Nazi, in an effort to centralize and focus the blame for such atrocities on an easily identifiable figure rather than a monolithic notion of "the Nazis." Other elements of the Hollywood paradigm include linear storytelling, omission of non-essential elements, invisible editing for better audience participation and closure at the conclusion of the film. Holocaust concludes with Inga and her brother-in-law Rudy accidently meeting in a café and realizing that, along with Inga and Karl's Christian son, they are the only survivors of the Weiss family.

${ }^{24}$ Barbie Zelizer, calls this characterization a "glorified and romanticized version" of the real Amon Goeth. However, her primary complaint appears to be that Goeth was "fat and pot-bellied" where Fiennes was only made to look a little chubby. His actions in the film are not in any way glamorous or romantic. See Spielberg's Holocaust, pp.18-39.
} 
cruelty of Holocaust, characterized by melodramatic, soap opera gesturing. He is the product not only of historic reality, but of the new Hollywood trend toward realistic violence onscreen and of Hollywood's belief that the viewing audience prefers to watch beautiful people in film rather than the reality of ordinary people. Goeth is therefore portrayed by a good looking actor rather than one who might come closer to the exact physical description of the man himself, but he is also a man capable of shooting a boy for being unable to remove stains from a bathtub or beating his Jewish housemaid because he is sexually attracted to her. The Nazi archetype as the cold and brutal, but otherwise average, German coalesces during Holocaust but solidifies in Schindler's List into the Nazi of the contemporary master narrative. That is to say that the master narrative immediately following the liberation of the camps understood the Nazi to be a raving lunatic, exemplified by the rantings of Adolf Hitler on the numerous newsreels of the time. Over the course of the following decades, objective examination of historical record revealed a very different Nazi and the master narrative slowly changed shape to include the claims of this new drone-like creature who only followed orders. However, both of the above filmic representations are the inventions of a Hollywood that believes audience participation in the suspension of disbelief relies on the representation of Nazism as more than a nebulous concept, but as a person through whom we can see the abstractions put into reality.

As a counter to both Dorf's and Goeth's roles as Nazism personified, the audience is presented with a clear example of Jew as victim, first in a familial representation, then as a series of individual Jews whose identity as victim is never 
questioned. Holocaust proposes the Weiss family as all conceivable incarnations of victimization by the Nazis, as well as the corresponding Jewish responses, although each must play multiple roles in order to accomplish this. They "are the symbol of the Jewish families who were destroyed by the various Dorfs during the Holocaust" (Doneson, American Film 159) but in being so, are also codified as the various Jews of the Holocaust.

Mrs. Weiss is the Jew most Americans want to believe never existed. She is the naïve and disbelieving victim, whose family becomes ever more endangered due her insistence that they are safe because she and her family are higher class, better educated Jews. ${ }^{25}$ She believes the family's position in society will save them. Her ignorance is self-induced and doesn't appear to consider the fate of her fellow Berliners. She is not interested in the preservation of the Jewish people as a whole, nor in the reality of what is happening to her neighbors and friends; she is only concerned with the individual fate of her family. Mrs. Weiss unwittingly plays into Nazi plans multiple times throughout the production, first, in allowing herself to believe that she is safe and the assurances of the Nazis are sincere, second in believing that her daughter is better in a German treatment facility rather than at home, and third in not making a fuss in the gas chamber. She trusts that her family will be the only ones in Berlin not affected by the Nazi takeover. She continues to believe the family safe,

\footnotetext{
${ }^{25}$ The objection is not to naivete in and of itself. However, as evidenced by American films from the beginning, we see ourselves as people who 'do something' when cornered and do not want to see films in which the protagonist is a hapless victim unwilling to fight back. The American western and action genres are based on this concept. Therefore, Mrs. Weiss is not only thoughtless in her inaction with regard to her family, but she is willfully naïve in the face of evidence that her world is crumbling, and violently so. She holds her beliefs until she enters the gas chamber. This is a trait Americans generally do not like in a film protagonist.
} 
even as the Helmses, her in-laws, become ever more hostile to her presence. She only leaves Berlin after none of her children are left. Her move to Krakow seems a holiday; her conviction in the pleasantness of the world holds until she is gassed to death at Auschwitz. She smiles and simpers and plays the piano as her Rome burns. In addition, she is the personification of Jewish acceptance of their fate in the concentration camps. When the women of her barracks are taken to the showers for gassing, Mrs. Weiss states to the Jewish capo who is escorting them, “you needn't lie to us," then charges the capo with telling her husband "what has happened." Her response is melodramatic and unrealistic given her character until this point. Although her response to danger results in the deaths of most of her family, Mrs. Weiss becomes the master narrative archetype for the Jew-with-her-head-in-the-sand, allowing her family to come to destruction because believing the alternative is too unpleasant in a world that has been so perfect until this point. Her husband, however, is equally distasteful as he allows her to ignore the ever-increasing danger to their family because it makes her happy to do so, and falls into the pattern of ignorance himself. As Lance Morrow described it "Dr. and Mrs. Weiss behaved in such genteel forbearance down to the last horror of the Zyklon B showers that their journey seemed like Mr. and Mrs. Miniver Go To Auschwitz."26 (Morrow, online, 1978)

\footnotetext{
${ }^{26}$ Morrow, as well as other critics contemporary with the release of the Holocaust, found the production distasteful due to its "soap opera tendencies" and "melodramatic" style. As these critics, including Elie Weisel and Claude Lanzmann, viewed the mini-series with an awareness of what was both allowed and available at the time it was filmed, I will defer to their knowledge of the appropriateness of the production for its time. Roots was released the year before but was not accused of melodrama although it contained images of trauma and violence which could have been treated similarly by its director. While there were certainly limitations as to what could be shown on network television in 1978, the various productions did not approach these limitations in the same way.
} 
Mr. Weiss indulges his wife's desire to pretend that their Germany remains unchanged throughout and, though convinced that the family must flee Germany early on, consents to remain, until he sees his eldest son Karl sent to Buchenwald at the whim of the Nazis and is himself deported to Poland, leaving his family in the hands of his German in-laws. His faith is in his position as doctor to the Jews of Krakow and in his wife, who he appears to believe is the personification of goodness, and who he allows to guide him. Echoing her misguided sense of reality, once he is ensconced in the Krakow ghetto, he continues his trust in the idea that the Nazis are being truthful and becomes part of the community council set in place to affect Jewish self-rule. These leaders are thereby a bridge between the Nazis outside the ghetto and the Jews forced to live inside in miserable conditions. But Mr. Weiss is also the voice of hope and of reason. He asks, while being marched back to the barracks for 'de-lousing,' "Why do we still obey them?" Then he discusses a hopeful outcome with his former patient, Mr. Lowy, all the while knowing the true meaning of the Nazi euphemism. Here, the American audience is reminded of the details of Nazi deception when discussing the concentration camps and their methods of extermination, a concept that was first introduced in Judgment at Nuremberg.

Their son Rudy is not only of a different generation and therefore less closed off in his view of the world, but is of a different mindset. He is the only realist in the family. Upon seeing his mother's folly, he runs away from Berlin in the middle of the night to join the resistance, a characterization of the Zionism that was largely ignored in Hollywood prior to the making of the mini-series. Judith Doneson states that 
“Gerald Green's script strengthens the Zionist viewpoint that Jews can fight, but that weak, passive diaspora Jews usually do not."27 (Film, 2002:171) In Hollywood's romantic notion of justice, Rudy, as the Weiss family resister, becomes the archetypal sole survivor of his family, a condition which will be alluded to in most survivor narratives that follow. His second role in Holocaust is that of the person who marries during the Holocaust. This is a phenomenon that did happen in the camps, generally as a traumatic response to losing the entirety of one's family and an attempt to carry out the mitzvah of procreation. ${ }^{28}$ However, in Holocaust, Rudy's marriage to Helena also serves as the romance factor necessary in Hollywood film and occurs while they are living in the woods, on the run with the resistance. Regardless of the complexities of war and their effect on the human psyche, this storyline seems melodramatic and implausible. Rudy and Helena fall into bed within an hour of meeting and she immediately decides to run away with him to join the resistance, leaving behind family and friends, thus taking up the romantic ideal of 'running away together.' But Helena is not the strong-willed woman who rescues Rudy from punishment by the Nazis in Czechoslovakia, with the confidence to run off and join the resistance moments after meeting a man to whom she attracted. She is at times the brains behind their escapes due to her linguistic abilities, appearing to be the ideal freedom fighter,

${ }^{27}$ Doneson, as well as Peter Novick, Jacob Neusner, Annette Insdorf and Noami Mendel document the tendency among some scholars to conflate the events of the Holocaust and the Six Day War, resulting in an inaccurate idea that the formation of the state of Israel was the direct reaction to the horrors visited upon diasporic Jews. This is further complicated by the fact that the majority of Holocaust records outside of Europe itself are housed at the Yad Vashem Institute in Jerusalem, which has established itself as the keeper of Holocaust memory.

${ }^{28}$ After liberation, while the prisoners were still housed at the camps, marriages and births came at a rapid pace. According to Michal Eisikowitz, during 1946 Bergen-Belsen experienced 1070 marriages, averaging 6-7 a day and up to 50 in a single week. His research and survivor interviews indicate that loneliness was the primary reason for marrying in the camps. 
but at the same time she is the weak and frail woman who cries whenever there is danger, a throwback to Classic Hollywood. ${ }^{29}$ Her presence in the miniseries is not to add to the public knowledge of the Holocaust and thereby become part of the master narrative, but to offer the requisite love story, one that cannot be fulfilled by the Karl and Inga Weiss marriage due to their spending most of the film separated from each other.

Likewise Anna, often histrionic in her resistance to her mother's head-in-thesand philosophy, is, at sixteen, portrayed as too young to be sensible of any real danger to herself and consequently becomes a victim of a brutal gang rape by Nazi officers. She descends into a madness born of the realization that there is very little that can be done to fight against an enemy who doesn't even consider her human. Anna plays the role of two archetypal victims simultaneously. First, as the victim of a sexual violence which is seemingly disassociated from the taboo against intimacy between German and Jew, she is the archetypal victim of the Nazi as sexually sadistic monster. ${ }^{30}$ Second, as the victim of death-by-gassing of the sick, frail and mentally infirm, she is the archetype of the uncontrollable deaths of the "other" as Nazi victim. While the category of other in the Nazi regime included political prisoners, homosexuals, resisters, gypsies and socialists in addition to the mentally ill, Holocaust

\footnotetext{
${ }^{29}$ In Classic Hollywood, men and women were expected act in proscribe roles. Men were believed to be tough and protective of women. Women, in turn, were seen as more weak and frail, in need of protection and rescuing. In the greater sense, American films no longer adhere to these rules.

${ }^{30}$ This particular archetype may have evolved from the very real documentation of sadistic tendencies in certain Nazi officers combined with the equally real testimony of Jewish rape victims. In all of recorded history rape has been included in the arsenal of weapons used in wartime. See Claudia Card,
} 
acknowledges their suffering by making Anna the personification of the combined 'others' who just happens to also be Jewish.

Conversely, Schindler's List creates an array of singular archetypes without the soap opera tendencies. This is the story of Oskar Schindler. Here, a shift is made away from the Jewish victims as central, while at the same time Spielberg focuses on Schindler's interactions with individual Jews as he effects their rescue. The character of Oscar Schindler is therefore the focus and the Jews act as extras in a story that is not about them, but about their rescuer. While Holocaust attempted to educate the viewing public on the reality of the destruction of European Jewry, its soft-soaping of the true conditions in both the ghettos and the camps, though proscribed by the television conventions of the time, was only able to initiate the discourse in film. But fifteen years, and the commemoration of multiple Holocaust memorials across the United States, had a profound effect on the tastes of the viewing public. No longer would vaguely dirty prison uniforms and pantomimed fatigue be adequate as signifiers of suffering. By the 1990s, Spielberg would be required to show the audience a more real reality than had been shown before. ${ }^{31}$ However, as the master narrative was already beginning to take shape in the minds of the American public it was also up to Spielberg to either affirm or discard the archetypes.

His protagonist in the film is not the Jewish victim but the potential perpetrator, a fact that Elie Weisel, and those like him, considered a travesty.

\footnotetext{
31 Claude Lanzmann's Shoah was in direct reply to Holocaust, which Lanzmann felt to be a trivialization of the catastrophe. However, Lanzmann, along with Elie Weisel and many others, have insisted that any production that attempted to recreate actuality could only be a trivialization and therefore Shoah does not make this attempt and must be regarded as a separate category of film than the fictional narrative discussed here. This will be discussed later in this thesis.
} 
Schindler is a member of the Nazi Party who only belatedly decides that he is on the wrong side and uses his position to the advantage of the Jews he rescues, though his reasons for doing so are unclear. However, at the many and varied times when all involved in the Holocaust are faced with choices, Schindler's prior life makes him fall back into old and familiar patterns which indicate to the Jews around him that they are in just as much danger from Schindler as from anyone else. When Itzak Stern forgets his work card and is subsequently taken to the trains to be transported to a work camp, Schindler scolds him. "What if I got here five minutes later? Then where would I be?" Stern realizes that his relationship with Schindler is based on his economic value as accountant rather than on any personal attachment, a value that may not always hold true and which immediately reminds the viewing audience of the arbitrary nature of existence in the world of the European Jew. Helen Hirsch, Goeth's housemaid, explains it to Schindler this way:

One day he will shoot me...I know. I see things. We were on the roof on Monday, young Lisak and I, and we saw the Herr Commandant come out of the front door and down the steps of the patio, right there below us. And there on the steps, he drew his gun and he shot a woman who was passing by. A woman carrying a bundle. Through the throat. Just a woman on her way somewhere. She was not fatter or thinner or slower or faster than anyone else and I couldn't guess what had she done. The more you see of the Herr Commandant, the more you see there is no set rules that you can live by. You can't say to yourself, 'If I follow these rules, I will be safe.' (Schindler's List, 1:40:50)

Goeth and Dorf, though different, both become part of the master narrative. Goeth is sadistic and cruel, the most commonly imagined characterization of Nazism, while Dorf is the man doing his job under orders, but who is always astonished at how easy 
it is to achieve compliance from the Jewish community, an acquiescence that doesn't dissipate even at the moment of death.

The archetype of the Holocaust Jew, however, begins to change form somewhat in Schindler's List. Rather than allowing for numerous types, such as the smiling or complacent or ineffectual victim, the Holocaust Jew morphs into a version more in line with the more recent incarnation of the master narrative of incomprehensibility imposed on the Holocaust by writers such as Elie Weisel. This group of Polish Jews does not understand what is occurring nor do they believe that any particular one of them is safe at any moment. Gone is the simpering smile and calm demeanor of Dr. Weiss and his wife, replaced by outward stoicism masking inward terror. These are people whose minute-by-minute existence is at the whim of those who hate them. They are never seen as anything other than victims of Nazi Germany, a status that is frequently reiterated throughout the film.

Perhaps the only exceptions to this, in opposition to Schindler himself, are the opportunists, the smugglers who later become part of the peacekeeping unit in the ghetto. They appear to be secure in the belief that since they are performing a service, they will qualify for exemption from deportation to the camps, or that such a fate will be delayed until the war is over. As a result, they deal with their fellow Jewish residents as though there were always time to enjoy the fruits of their dealings. There is no compassion for the people in their charge, just as Mrs. Weiss feels none for her neighbors. The opportunists only live for the accumulation of wealth, as Schindler does prior to his enlightenment. These Jews-as-collaborators not only enter 
the spotlight of the master narrative at this point, but do so in a way that stokes the flames of Holocaust denial. ${ }^{32}$ The additional archetype of victim-as-perpetrator is born of the portrayal of these opportunists. Though these men did not kill or torture their fellow countrymen, they are seen as a strange conglomeration of bystander, collaborator and perpetrator, but rarely as victims themselves, regardless of their inability to escape the same fate as those around them. While documentation suggests that the capos of the camps and guards of the ghettos were replaced regularly, as they had no increased value to the Nazis, Schindler's List relies on the ability of Stern to bribe one man into transferring the Schindler Jews to the factory. The reality of the replacement of these individuals would require the enactment of a different plot line to achieve the required goal and is ignored for a better and more cohesive production. This reality makes sense within the film even as it fails to do so in reality. The opportunists witness their people being sent to the camps as the Krakow ghetto is emptied but the act of witnessing has little effect on their own sense of reality.

When we compare the two productions, the opportunists, as well as the other, limited examples of witnesses in each are similar but the bystander archetype is profoundly different. In both instances, the witnesses are single individuals with little effect on either the outcome of the war or the fate of the victims. In Holocaust, Uncle Kurt Dorf, a roadbuilder, witnesses his workers marching to their deaths, an event he

\footnotetext{
32 The Holocaust Jews have routinely been accused of collaboration in their own destruction, however, until Holocaust in 1978 and Schindler's List in 1993, this idea was not given credence in film nor was it explained as to how anyone might come to that conclusion. These two films touched on the personification of this accusation in a way that attempts to give explanation while at the same time, unintentionally, adding to the denial argument.
} 
is powerless to stop. In Schindler's List, the witness is the single Russian Army liberator, the last person to recognize the Jews of Plaszow as prisoners. In contrast, Holocaust's bystanders are of two types, those who are silent and those who are not. As Karl Weiss is led away by German police, the numerous bystanders first watch, then quickly close their doors, as Inga races frantically after her husband and his captors, silently allowing the arrests to go unquestioned. The Helms family, however, is increasingly vocal in their disdain for the position they believe themselves to be in following the marriage of their daughter to a Jewish artist. Their bystander status straddles the line between bystander and collaborator in their incessant insistence that Inga give up her in-laws to the Nazis. Additionally, Marta Dorf appears as the bystander who not only stands by and watches as her own physician and his family are taken away; she actively acts as witness against them when she harangues her husband for his cowardice for questioning his involvement in the Final Solution. She is not even remotely moved when she discovers that the piano she has been given is the same one that belonged to Dr. Weiss. Schindler's List similarly focuses on the latter type, the vocal hate-spewing German now part of the master narrative. As the Jews of Poland report to the Krakow ghetto, a little girl stands on the street screaming, "Goodbye, Jews! Goodbye, Jews!" and becomes a vocal track which bridges the scene of the exodus with the mass entry into the walled ghetto, another, more visual, element of the master narrative.

The walled ghetto is not the only visual reminder of the horrors of the Holocaust however. Schindler's List is rife with graphic depictions of Holocaust 
iconography. From the beginning of the film to the end, the audience is bombarded with the real. We are never allowed to forget where we are. We watch the poor and wealthy alike pack their belongings and leave their homes only to arrive in a cramped and dirty ghetto where they must share living space with dozens of others. We see the people dying in the streets of gunshot wounds, the muddy camps, the barbed wire and guard towers. In this realm of the visual, however, Holocaust stands out for the sheer oddity of its handling of visual elements that would otherwise not fit in the production, as well as for its superficial use of key elements of Holocaust history to illustrate the plot. First, we are witness to the burning of a synagogue in the most arbitrary plot diversion of the mini-series. Nothing leads up to the burning. Instead, we watch Hans Helms as he watches the synagogue burn without emotion. This scene is immediately followed by a scene in which Dorf is presenting a slideshow to General Heydrich of black and white photos of the tortures and killings at the camps. We can only presume that this is part of a regular report from the camps since it occurs again later in the film and we are told early on that Heydrich is "in charge of them all." The combination of the burning and slideshow scenes create a catalog of visual images that we are meant to remember without the acts they depict actually being part of the film.

Strangely, while the icons of the horror of the Holocaust are being burned into the public consciousness, at the same time the master narrative of WWII and the destruction of European Jewry appears to be evolving into a construction that does not include nor recognize Adolph Hitler as an element. Both Holocaust and Schindler's 
List leave out any mention of Hitler, as do most of the films discussed later in this thesis. ${ }^{33}$ The war of cinematic representation appears to be one concocted by Hitler's subordinates, the Final Solution planned by underlings of the Reich rather than by the Chancellor. Hitler seems no longer to be synonymous with the Holocaust, but is being replaced by an amorphous entity known as "The Nazis," all of whom claimed to be taking orders from a higher level, and yet, the highest level seems no longer to exist. This phrase very often tends to be synonymous with the idea that all German citizens of the 30s and 40s regardless of their involvement as Nazi officer, witness, collaborator or bystander, were in fact all Nazis, as if the American consciousness needs to believe that in order to allow the Holocaust to happen, all German citizens must have been involved in the Nazi party in some way. Furthermore, as the Nazis represent the perpetrators of the Holocaust, Auschwitz represents the victims.

When the word Auschwitz is mentioned in any form of discourse, it carries with it an enormous amount of imagery, an encyclopedia of information that the hearer of the word conjures instantly and without further explanation. Auschwitz can be said to both contain the master narrative of the Holocaust within it and be a metaphor for it. Auschwitz is not simply a town in Poland where a concentration camp came to be built. Auschwitz is 6 million dead Jews, starvation and disease, Dr. Mengele's medical experiments, the brutality of the cattle cars transporting the

\footnotetext{
${ }^{33}$ This may be due to an assumption that the public at large knows Hitler's role and therefore writers and filmmakers believe that storytelling can take place on other levels of the Nazi regime, focusing on the less obvious candidates. However, as future generations view and record history through the varied media of storytelling, there is the very real danger that public consciousness (in America) will lose the knowledge that WWII was the direct result of Hitler's war on European Jews. This anxiety is aimed at the general public, not at students of history nor at academia where presumably the involvement of Hitler is known.
} 
prisoners to the camps and a never-ending sea of victims. More than that, however, Auschwitz has come to be known as a temporal location, a place in time where immense trauma is located. Most importantly, the notion of Auschwitz in public memory cements the Holocaust master narrative in a way that no other term can. The mere mention of the name conjures up images of crowded bunks, emaciated prisoners, mud, human filth, shaved heads, arm tattoos, body-sized ovens, piles of human corpses, guard towers, guard dogs and barbed wire. In other words, "Auschwitz" contains the catalog of appropriate mise-en-scene for any Holocaust film which goes beyond the simple definition of the word. Without these elements, we are not looking at a Holocaust film, but a forgery. 
Chapter Four: A Study of Documentaries and Fictional Film in Relation to the Holocaust Master Narrative and Its Effects on Storyline

Within the vast array of cinematic representations of the Holocaust, there are many subcategories, which begs the question, "Are some representations of the Holocaust better than others?" The answer, in short, is yes. And no. It depends on what is meant by 'better.' If we mean, Are there Holocaust films that are more deserving of praise as films, irrespective of their content, then yes. If however, as Weisel, Lanzmann, and others would have us believe, there is no such thing as a good representation of the Holocaust because the Holocaust cannot and should not be represented as fictional re-enactment regardless of the sensitivity to the subject, then no. "One does not imagine the unimaginable. And in particular, one does not show it on screen." (Wiesel, Shadows, xi) This dialectic asks audiences to perceive all Holocaust films as bad because they dare to speak the unspeakable, rather than believing that all Holocaust films are good since the more times the stories are told, and as the details become more numerous and more clear, the greater the chance that the conviction 'never again' may be realized. Any Holocaust film's measure of goodness or worth, therefore, is based on criteria from two opposing sources, those who are judging the film as a piece of history represented on film and those who are judging the artistic merits of the film as art.

For purposes of this thesis, this debate is moot. Herein, analysis begins and ends with identification of the elements of the Holocaust master narrative as they are employed within each film. The relative merits of the films themselves are 
immaterial. Instead, we will address fiction and non-fiction storytelling in cinematic representation specific to the Holocaust and discover how these cinematic constructions use the master narrative to aid audience reception. It is important to note that those films which only marginally deal with the Holocaust, such as $A$ Secret, will be addressed here as well, as these films use the master narrative in an interesting way that cannot otherwise be used in Holocaust focused narratives. Though the following study encompasses many films and their types, it is not in any way a comprehensive accounting of all Holocaust films.

\section{A. Documentaries}

The French film Night and Fog adds to the master narrative's visual references, but only as the details exist to describe the aftermath of the Holocaust. The film is unrelenting in its photographic style, as it forces the viewer to linger on pile after pile of shoes, eyeglasses, shorn hair and family photos. Although the written works of Elie Wiesel and Primo Levi describe the camps as the men experienced them, and therefore these elements of the master narrative existed prior to the making of the documentary, the impact of the visual image is more direct and less inclined to interpretation. The audience is bombarded with image after image of what was left behind. That is, we see the mountains of skeletal bodies being bulldozed into open pits or the endless rows of open latrines and are left to let our imaginations recreate the events that led to what we are viewing. However, this is only possible due to public knowledge of the event in history but was likely incomprehensible at the time the film was made, given that the footage contains images captured shortly after liberation of 
the camps, at a time when there was little public awareness of the horrors of the Holocaust.

Much later, following the television debut of the mini-series Holocaust, Claude Lanzmann created the lengthy documentary Shoah to document the Holocaust and honor its survivors in a way he felt was more respectful of the suffering. He believed his non-documentary, non-narrative film to be the only proper way that the Holocaust could be represented. He calls this method "the fiction of the real." (Lanzmann, 1990:295) The film, and its collection of interviews of survivors, bystanders and perpetrators doesn't have a linear feel, nor does it actually tell a story so much as force the witnesses to expose themselves before the camera in a way that feels unnatural and invasive. When asked why he is talking about the Holocaust if he doesn't want to do so, survivor Michael Podchlebnik replies, "Because you are insisting on it." (Shoah, 1985) He weeps when he is coerced into revealing that while on a Chelmno work detail, he was forced to unload the bodies of his wife and children from a gas van and throw them into a pit for burial. Later, Itzhak Dugin, after recounting for Lanzmann the scene in January of 1944 where he was part of a work detail forced to open the mass graves at Vilna, is asked "Who in your family did you recognize." His answer, "My mother and sisters. Three sisters and their children. They were all there." Lanzmann has exposed a nerve and prods it further. "How could you recognize them?" Dugin answers, “They were relatively well-preserved." Lanzmann appears not to be concerned by the pain he is causing these victims. Instead, there is a sense of 
equal treatment for everyone. Victims, perpetrators and bystanders are all prodded to expose themselves to Lanzmann's camera in the same manner.

Shoah is, however, immensely valuable in the documentation of the master narrative in that it exposes three archetypes as we witness them solidify on screen. Here, it is Lanzmann who creates the viewpoint of the Jew as the stoic and somewhat passive survivor of atrocity. As the individual survivors tell their stories, the burden of horrific memory is apparent on their faces and yet Lanzmann pushes them on. Where a narrative or fictional film would depict the horror as it unfolds, allowing the viewer to attempt understanding through the fantasy of 'film as reality,' Shoah assaults the survivors along with the bystanders and perpetrators, creating only pity for the victims rather than forcing those who were not there to watch the scenes as they happened. While this may be warranted for the perpetrators in that it forces them to relive, and face up to, the violent acts they committed, to do so to the survivors seems unnecessary and editorializes in a way Lanzmann claims not to do. He states, "It is in this moment that the truth is embodied." (Lanzmann, 1990:298) We are made to feel pity for them as they struggle with their memories. Empathy, however, is disallowed by the structure of the film. The survivors, made self-conscious by the presence of camera, translator and director, attempt to maintain a stoic façade while describing atrocities they could not stop and were forced to participate in. Moreover, his declaration implies that the survivors, thrown into the same category as the perpetrators and bystanders, are somehow disembodied from their memories until this point, something that is clearly not accurate. There is a certain amount of arrogance in 
the implication that Lanzmann's subjects have become separated from their own memories of the tragedy and that his insistence on making them relive the memories is a way in which they may return to the embodiment of their traumatic past.

Similarly, the archetypal Holocaust bystander is cemented on screen from the viewpoints of both bystander and survivor. Czeslaw Borowi relates his witnessing of the transportation of the Jews to Treblinka in a dispassionate manner. "The Jews came into the camps and then the people vanished." When pressed about what he thought was going to happen to the Jews on the passing trains, he distances himself. He speaks in terms of the village as a whole, a group he seems not to be part of. "They were appalled and they commented privately that in the history of the world no one had ever murdered so many people that way." Borowi is not part of the 'they' who stood by and watched, instead he is acting as witness to the bystanders. Further into the interview, Borowi laughs at the memory that he frequently stood near the tracks and made gestures to the prisoners indicating that they were about to die; he does not feel remorse for what he continues to believe was a fairly comical gesture.

Lanzmann establishes the bystander as always 'them, not us.' However, this is marked by two distinct types. In addition to those, like Borowi, who don't consider themselves as actors in the scene, there are those who admit that they stood by but without any apparent understanding of their complicity through inaction. In either case, the bystander does not consider his crime as such. In the scene following the interview with Borowi, two men laugh as they tell their account of trying to watch the asphyxiations but being chased away by Ukrainian guards with gunfire. The two 
appear like little boys attempting to sneak into a ballgame for free, rather than witnesses to horrific crimes. Later, other bystanders tell of how they 'got used to' the screams from the camp. None of the bystanders show remorse, apparently believing themselves guiltless.

In contrast, the survivors blame their neighbors as well as themselves for not acting against the deportations. Inge Deutschkron went into hiding in 1943 when the deportations began in Berlin, a place she no longer considers home. "They didn’t know. They say they didn't see. 'There were Jews living in our house one day and then they were no longer there. We didn't know what happened.' They couldn't help but see it." Here, we can see that the bystander is consistent in his or her denial of guilt, if not of ignorance.

The perpetrator archetype is far more complex, while at the same time, more simple. The perpetrator has been fossilized in the public memory as the monster who may, on a whim, snap the neck of a child, shoot a family of Jews, rape a woman and her daughter, while at the same time he will have a wife and children or show kindness to animals. Such descriptions were given in the testimony of survivors at Nuremberg. Witnesses recall seeing Nazi officers tear babies apart, then feed dogs from their pockets. The archetype is similar to that of the serial killer in recent forensic dramas. However, the fact that this particular serial killer is joined by tens of thousands of his friends and his killing spree ends in the deaths of six million European Jews and untold others, makes the Nazi the archetype of a singular kind of evil. In any future narrative, the Nazi becomes the history's most reliable villain. He can do anything 
evil, horrifying or sadistic and the reader or audience accepts his actions as a matter of course. The Nazi is the villain without parameters. Whatever his actions, it is expected, as the Nazi is the personification of evil. What is never accepted, or expected, is that the Nazi is ordinary, pathetic, banal. Hannah Arendt's description of Eichmann's ordinary person, conveying a "banality of evil" challenges the master narrative but simultaneously has left a the door open for filmmakers to create narratives describing many other such uninteresting characters. In Shoah, Lanzmann provides an illustration of non-evil evil. Hans Suchomel, a former SS Ünterscharführer, is now an old man with a heart condition. He maintains that he was unaware of the purpose of Treblinka prior to his arrival. But, he says, "As we went by, they were opening the doors of the gas chambers. The people fell out like potatoes. Naturally that horrified and appalled us. We went back and sat on our suitcases and cried like old women. Each day 100 Jews were chosen to drag the corpses to the mass graves. In the evenings, the Ukranians threw those Jews into the gas chambers or shot them." Like the bystander, Borowi, Suchomel separates himself from the people doing the killing. He speaks in detail of the workings of Treblinka and his time there without ever admitting that he perpetrated any crimes. He falls back, instead, on the outcome of his trial, that he was not responsible. He describes the workings of the camp, describes his disgust at seeing the mountains of bodies "piled up like wood" but doesn't appear to connect himself and his job at Treblinka with the outcome. The perpetrator of the master narrative and the testimony of the still-living executioners battle for the dominant position in film. Whereas the 
testimony of the survivors is considered sacrosanct in that their words are never questioned, testimony given by the perpetrators is always suspect. Rarely does the guilty admit his guilt.

However, it is not only the archetypes of individuals that come out of the early narratives. Important components of the master narrative of the concentration camp are also described in Shoah, as they had been previously in the works of Primo Levi in 1958, with Survival in Auschwitz and Elie Wiesel in 1972 with Night and in the miniseries Holocaust. ${ }^{34}$ The first is the notion of trains as conveyors of death and the markers of the entrance to a future of torture. Levi describes his experience.

We suffered from thirst and cold; at every stop we clamoured for water, or even a handful of snow, but we were rarely heard; the soldier of the escort drove off anybody who tried to approach the convoy. Two young mothers, nursing their children, groaned night and day, begging for water. Our state of nervous tension made the hunger, exhaustion and lack of sleep seem less of a torment. But the hours of darkness were nightmares without end. (Levi, 18)

Wiesel's is similarly grim. "Lying down was not an option, nor could we all sit down. We decided to take turns sitting. There was little air [...] After two days of travel, thirst became intolerable, as did the heat" (Wiesel, 1972:41). However, Holocaust shies away from attaching a visual representation to the description of the trains; instead, the train pulls away from the Warsaw ghetto station at the end of Part 4, prisoners reaching out of the barred windows and waving goodbye - but to whom is a

\footnotetext{
34 These three narratives are not the only post-Holocaust works prior to 1985 to focus all or part of a text on the trains. They are, however, the most recognized, with the exception of Raul Hilberg's Destruction of the European Jews, which laid out, in detail, the mechanics of the use of train cars in carrying out the transport of Jews to the camps. The original version, in three volumes was published in 1961. Additional analysis of the miniseries Holocaust is being included in this section due to the claim by Claude Lanzmann that he made Shoah in response to the television film.
} 
mystery since there is no one left. It isn't until twenty minutes into Part 5 that we see Dr. and Mrs. Weiss ensconced at Auschwitz. Again their simpering smiles belie the reality of the camp itself and the memory of the journey there by train. The opportunity to visually illustrate the conditions in the cattle cars is lost and the audience is left unknowing, but for the narrative descriptions given in various texts.

Lanzmann similarly refuses visual contact with the trains. Instead, he interviews survivor Abraham Bomba in a seaside café in Tel Aviv. "People were not only starving but they was $[\mathrm{sic}]$ choking. It was hot $[\ldots]$ it was hot like Hell $[\ldots]$ There was not a drop of water." Although all accounts are the same, there appears to be a taboo on the visualization of the area inside of the trains at this point.

This taboo seemed to be ignored, at least partially, in Schindler's List. There, the audience sees Itzak Stern taken by train to the Plaszow camp. We see Stern stand during the entire journey with others crowded close to him. We see the desperation for water in the hosing down of the cars during a stop and the utilization of icicles as a water source. But never does the camera venture inside the cars further than what can be seen in a small pool of light from the barred window. It isn't until the late 2000's that we begin to see further into the cars and can visualize the trauma of the cars for ourselves. Although there is no concrete documentation as to the reasoning behind this, it may have been due to a lack of information as to the true conditions combined with the relative newness of putting the realities of those conditions on film.

The second element of the master narrative cemented here is the idea of Auschwitz as metaphor for evil, horror, all concentration camps and Jewish death. 
The narratives of Levi and Wiesel have described the place of ultimate horror, a place both were lucky to survive. Holocaust once again skirts the edge of the reality. It first alerts the viewer that the Weiss' are about to experience the worst of all concentration camps with the lines, "Change in plans. Treblinka is full. You're going to Auschwitz," only to make Auschwitz a place of doctored reality, a Hollywood-style flattening of the concentration camp as locus of atrocity. ${ }^{35}$ In Holocaust, there appears to be no work details for the women, who lounge in the barracks free from the grueling (as far as this film is concerned) tasks given to the men. From the various writings following the liberation of the camps, including news articles and newsreel footage, Auschwitz inhabits the public memory as the locus of crimes against humanity and has become synonymous with the Holocaust. However, the mini-series waters it down in an attempt to make the experience of Auschwitz palatable to television audiences. While the censors were likely satisfied with the final product of this visualization, it is specifically designed to tell the viewer nothing about the experience of being there. When Dr. Weiss and Mr. Lowy work hauling cement or spreading asphalt, the only indicator of the difficulty of the tasks is the melodramatic acting and clothing spray-painted to appear dirty from a distance. There are no shaved heads or emaciated prisoners, no tattoos or believable back-breaking work. ${ }^{36}$ In this case, the master narrative is only hinted at in the vaguest sense. The viewer is led to

\footnotetext{
${ }^{35}$ This is not to say that the other camps were in some way better than Auschwitz, only that there is the perception that all camps were exactly alike and that to say "Auschwitz" means to say "concentration camp" and that a concentration camp was a where Jews were put to death.

${ }^{36}$ Holocaust was made in response to the release of the mini-series Roots, a production that showed a remarkable amount of violence for its time. Holocaust, however doesn't continue this by showing an acceptably realistic view of the camps. Instead, the production is water-down to resemble a time in television prior to Roots.
} 
believe that what we are about to see are the horrors of Auschwitz, but instead is diverted from the atrocities of the camps by watered-down visuals shored up by the knowledge which the audience brings to the film in the form of the master narrative.

Levi describes his own arrival at Auschwitz, entirely different than allowed in the film. "The climax came suddenly. The door opened with a crash and the dark echoed with outlandish orders in that curt barbaric barking of Germans..." (19) Weisel describes a similar scene. "Abruptly, the doors opened. Strange-looking creatures, dressed in striped jackets and black pants, jumped into the wagon. Holding flashlights and sticks, they began to strike at us left and right, shouting 'Everybody out!'” (46) Shoah uses Holocaust's technique of avoiding video references, while at the same time restating the information contained within the Auschwitz metaphor by using testimony which sounds like the writing of Levi and Wiesel. Rudolf Vrba, a survivor, explains the arrivals of the trains.

They didn't know what this particular stop means. The door was opened and the first order they were given was "Alle har aus." "Everybody out." And in order to make it quite clear, they usually started with those walking sticks to hit the first, the second, the third. They were like sardines in those cars. (Shoah)

Lanzmann has attached himself to the master narrative of arrival at Auschwitz as already established in the written texts above. By using an articulate witness who describes the arrival in the same language as that of Levi and Wiesel, Lanzmann joins the survivor discourse without the necessity of being a survivor himself and his authority, along with that of the master narrative, is solidified with this film. 
Again, if we look at Levi's description, Auschwitz' master narrative epitomizes the arbitrary nature of survival.

They did not interrogate everybody, only a few: 'How old?

Healthy or ill?' And on the basis of the reply they pointed in two different directions...In less than ten minutes all the fit men had been collected together in a group. What happened to the others, to the women, to the children, to the old men, we could establish neither then nor later: the night swallowed them up, purely and simply. (19-20)

Wiesel's account is again similar. "Every few yards there stood an SS man, his machine gun trained on us. Hand in hand we followed the throng. An SS came toward us wielding a club. He commanded: 'Men to the left! Women to the right!'” (47) In Shoah, Abraham Bomba describes his arrival at Treblinka. "We started one way to the right, one way to the left... We had no time even to look at each other because they started hitting us over the head..." All three of the narratives verbally describe a selection process which will become part of concentration camp history and which has frequently been used in Holocaust film. In Life is Beautiful, Guido and Giosue are sent in one direction away from the train. Guido panics and begins searching for his wife, whom he finds in a stream of women flowing away from the train in the opposite direction. Interestingly, the master narrative is essential to audience understanding of this scene and those resulting from it. Both historical fact and the master narrative of Auschwitz disallow the possibility of Giosue being allowed to stay with his father. Children who were not immediately killed were sent with their mothers to the women's barracks, but even then it was a temporary arrangement usually signifying that the entire women's barracks was headed for the gas chambers 
immediately. That Giosue remembers it differently tells the audience that Guido's ruse for the benefit of his son was ultimately successful. The child retains nothing of the reality of Auschwitz except the inevitable realization that his father has been killed, something that is not illustrated in the film.

This sunny outlook on the selection process acts in complete opposition to a more realistic scene depicted in Out of the Ashes, though both rely on the master narrative set up by Levi, Wiesel, Lanzmann and others. Dr. Perl has been explaining her role at Auschwitz for a tribunal of American investigators in 1946 when she attempts to emigrate to the United States after the war. Following one of the interrogations, she hears a Strauss waltz which provokes an emotional flashback to the night of her arrival at Auschwitz. Dr. Mengele whistles the same waltz while choosing who will live and who will die. Perl witnesses the separation of her family, and inadvertently sends her son to the gas chamber as she volunteers him to stay with an ill family member. The midnight arrival, spotlights and filthy conditions described by the master narrative are all present and the audience watches in horror as we understand what has happened to her son, though she does not. Again, the film relies on public knowledge to fill in the gaps where the story remains untold. ${ }^{37}$

Documentary contribution to the master narrative as it pertains to Auschwitz is not limited to the above examples, however, these illustrate how the various components that we see within later films come to be used as they are. Shoah, as a

\footnotetext{
${ }^{37}$ It is important to remember that the master narrative is made up of historical fact, myth, legend and personal stories. The master narrative of Auschwitz, including the elements here, is based on fact. That is to say that not all, of even most, of a given master narrative is invented and that empirical data is always included within the public's knowledge.
} 
spoken version of the written narratives of Primo Levi and Elie Wiesel, shores up the master narrative and acts as a slightly more objective accounting of survival.

\section{B. Fictional Cinematic Representations}

In large part, the body of Holocaust films with a fictional narrative structure, as opposed to documentaries such as Shoah or Night and Fog, is composed of biographies. There seems to be a publicly held perception that 'real stories' about 'real people' are preferable to fictionally conceived stories. Though Trudy Gold calls the bulk of these films "survivor's tales," (Overview, 194) they are not so limited. This list is no longer composed entirely of survivor narratives, such as The Pianist or Out of the Ashes, it also includes biographies of rescuers (Schindler's List), bystanders (Toyland), resisters (The Black Book), perpetrators/collaborators (The Reader), ${ }^{38}$ and the newest, and strangest, category, non-survivor narratives $($ A Secret $){ }^{39}$ Certainly, Holocaust films almost always result in the survival of European Jews (with the exception of non-survivor narratives) otherwise fated for the camps, however, Jewish survival is not always, or even mainly, the focus of the films. As we have seen with Schindler's List, these narratives may follow the development of a non-Jewish protagonist, in this case, as he interacts with both Nazi Germany and Polish Jewry. Therefore, rather than divide the films strictly into the categories of either biographies or non-biographies, the biography category will be sub-divided into films which deal with each of the protagonist types listed above, as the use of the master narrative is

${ }^{38}$ Resister and collaborator narrative films are relatively small in number and tell us little of the Holocaust master narrative in the way of innovation or usage. Therefore, for the purposes of this thesis, these two categories will not be explored herein.

39 This will be explained fully further on in the chapter. 
dependent on the protagonist for the appearance or non-appearance of particular elements in the individual films. The common thread between these sub-categories is that regardless of the subject of the film, who we are focusing our attention on in any given narrative, the films, more often than not, proclaim to be the story of someone who lived through the experience, imbuing the productions with a certain amount of inherent perceived truth. The Holocaust inhabits these films in a way that isn't possible in a purely fictional narrative film. These films are not biographies in the sense that they elucidate for the public the lives of interesting people and how they came to be who they are, as in the case of Walk the Line (2005) or Coal Miner's Daughter (1980). Instead, these films are centered around the Holocaust as the defining moment in lives we, especially in America, may not have otherwise known about and the biography tends to focus on the Holocaust as it pertained to the protagonist.

The Pianist (2002) is the biography of Wladyslaw Szpilman of Poland and will begin our discussion of the sub-category of Survivor Narratives. This film, as a depiction not of the camps but of the alternative for someone who has 'escaped' the deportations, is steeped in master narrative data. Due to prior knowledge of what to expect in a film involving Holocaust survivors, cemented in the minds of the viewing public by Holocaust, Schindler's List, and others, the film begins in the middle, as it were, exhibiting no need to establish backstory on what leads to the bombing of the radio station in the opening sequence. The audience already knows the 'history' of the Nazi invasion of Poland as seen in the Spielberg film. The only requirement of the 
film's narrative is to tell the individual story, since the time required to explicate the particulars of history up to this point is redundant and the filmmaker may begin with the protagonist's life as it relates to the event in question. The only backstory required is that of Szpilman's life prior to the bombing; he is a concert pianist working for a Warsaw radio station. Therefore, the master narrative is used not only within the complex world of the film itself but outside it as well. The master narrative establishes the world of Nazi occupied Poland as it exists within history. It is assumed that the audience knows what has occurred prior to this point in time within the realm of Nazi Germany's overthrow of various European governments and will apply that knowledge to the story as it unfolds. Due to this assumption, we must also conclude that the target audience are those people already familiar with, and interested in, Nazi Germany, since those without the WWII master narrative as part of their general knowledge of contemporary history would likely be lost and be unable to grasp the subtleties of the film's storyline and mise-en-scene. Within this film, therefore, knowledge of the master narrative is essential.

We expect to see mise-en-scene which includes emaciated bodies lying in the streets, or the wall surrounding the Warsaw ghetto, or in the scene where the Szpilman family is put to work in a ghetto work house, the mountains of belongings being sorted and stacked by Jews who must pretend not to know that they may have known the people who's belongings they are touching. However, we also notice plot points that can be matched to public knowledge. One of the first scenes that coincides with the master narrative is the scene in which a family friend comes to offer Wladyslaw and 
his brother jobs working for the "Jewish Police." We know from the master narrative that this position in the Warsaw ghetto was safer for a man willing to perform it than would otherwise be possible for someone without such a position but that it also meant exploiting fellow Jews and possibly collaborating with the Nazi regime. Therefore, understanding of the vitriol with which Henrich replies is dependent on knowledge of the master narrative. Without this knowledge the heated rejection of a job, at a time when jobs were almost impossible to come by, seems odd.

Similarly, when the Szpilmans, with the exception of Wladyslaw, are being loaded into cattle cars at the train station, the audience knows where they are going. Deportation from cities and towns in Poland is largely understood to be a sentence to Auschwitz. However, we learn later that this assumption is only partly true; while the family is certainly deported to a concentration camp, Wladyslaw is informed that the resistance has followed the trains and they have been diverted to Treblinka.

Conversely, this film also adds two elements to the cinematic version of the master narrative that, until this time, had been ignored either due to a taboo as set by the unwritten laws of Holocaust representation or by an inherent distaste that the representations would entail. The first takes place in the massive courtyard, where the Jews await deportation. A woman continually cries, "Why did I do it?!" What she is referring to, as it is explained to the Szpilman family a little later, is that she has smothered her infant in an act of desperation, rather than have the child endure whatever tortures awaited. Though desperate acts were certainly performed and this was likely not an isolated incident, film has tended toward leaving this element out of 
the narrative. However, this taboo appears to be receding, since a similar act is depicted in Out of the Ashes as Dr. Perl smothers her neighbor's newborn at Auschwitz rather than allow the infant to come into the hands of Dr. Mengele. The second element comes at the scene wherein Wladyslaw is rescued from deportation and is wandering the streets of the Warsaw ghetto, unsure where to go. As he approaches his former residence, he comes upon the bodies of children. Most of the audience, through knowledge of the Nazi atrocities, is able to recognize what they are seeing. One of the younger children lies in a bloodied heap at the foot of a stone wall, above him is a large splatter of blood. Through the stories of Primo Levi ${ }^{40}$ and Elie Wiesel, we are aware of stories of children being killed by smashing their heads against walls, railcars and poles. In this scene, we are greeted with the same horrors that Szpilman is, we cannot chose to have the particular piece of the destruction hidden from us. Both of these scenes, although generally existing within the historical master narrative, are only recently being added to what is portrayed on film with regard to the Holocaust. While they are not new elements within the public's knowledge, they are new to visual representation and therefore may add to the master narrative in the memory of those not familiar with non-cinematic representations of WWII.

The controversial Life is Beautiful is also a survivor narrative, but with a twist. The argument is that Roberto Benigni created a film in which the Holocaust is viewed as the backdrop for a fable and that such a film, which views the Holocaust through

40 Survival in Auschwitz. Trans. Stuart Woolf. New York: Simon and Schuster, 1958. 
the eyes of a child who is told it is a game, only trivializes the enormity of suffering present during the Holocaust. However, "the intentional creation of an optimistic Jew who averts his eyes from the signs of impending tragedy" (Viano, 31$)$ is one of any number of character types which exist in real life, and are therefore available to the filmmaker. The film allows the audience to see a different viewpoint of the Holocaust while at the same time keeping an eye on the master narrative as its underlying matrix. Bathrick asks "What, finally, does a focus on the representation of children in certain films about the Holocaust have to tell us about problems of remembering and memorializing on the part of the larger Jewish and non-Jewish collectives?" (42) The answer, certainly, is going to depend on the individual film.

Life Is Beautiful informs the audience of two very important things. First, that unlike many of the Holocaust focused films prior to this, the priority for the protagonist is to protect the innocence of his child, not just the child himself. The master narrative then plays as a set of visual cues that locate us within the Holocaust, a reality which the audience must acknowledge, while at the same time an adult Giosue layers the master narrative with his own remembrances of Auschwitz as described by his father. The child is allowed to retain the shield of innocence, something Guido cannot afford for himself, and therefore remembers Auschwitz not as it was but as his father wanted him to see it. However, for Guido, Dora and the audience, the Holocaust is never out of sight, nor mind. The cattle cars remind us that the little family is being swept into the Nazi machinery, and will likely not survive the ordeal, but this does not deter Guido from the hope that they will survive. This hope is 
evidenced in the elaborate narrative Guido provides to describe the death camp for his son, a hope that should they survive, the child will need to remember it differently. The barracks look enough like Auschwitz to make us aware of where we are, but aside from the basic elements of the master narrative, the thin prisoners, the striped clothing, the multiple bodies in a single bunk, the barracks is not quite right when viewed through our public knowledge. The room is too clean, too open. It is, in effect, the child's memory imposed on the master narrative and presented in discrete units that feel like the disjointed images imprinted on the mind of someone too young to understand their significance or to see the ways in which they fit together in a more continuous string.

The remaining argument that this film makes is that regardless of the story itself, the master narrative is primary to our understanding. We are reminded that what takes place on screen is as weighted with master narrative data as what doesn't. As the Nazis begin to pull out of the camp, Guido's Bartolemeo is adamant that they should not get in the trucks that are carting prisoners away. The master narrative has already given us enough information prior to the start of the film to know that the trucks will take people away to be shot. The trucks, therefore, represent death, a finality that cannot be escaped. Previously, as Guido becomes lost after waiting tables at an officer's party, the fog envelopes him and he finds himself standing in front of a mountain of bodies. However, without knowledge of the significance of this sight in history, Guido's emergence from the fog followed by such a discovery would be a thing of horror films, or nightmares. The master narrative dogs Guido in a way that 
disallows his ability to fool himself as he does Giosue. Whenever there is a possibility that Guido might forget his own reality, he is confronted with it head on. An encounter earlier in the evening provides another example. Here, the film reminds the viewer of the Nazis' belief in their own victimhood. The doctor, whom Guido believes might be able to get them out of the camp, instead pleads repeatedly for Guido's help. The ludicrous nature of his plea for assistance in figuring out a riddle while Guido and his family face death re-enforces the master narrative structure where the Nazi is convinced of his status of victim in the war, a position which made the Final Solution necessary. Overall, the story told in Life is Beautiful is unrealistic; ${ }^{41}$ however, it not only utilizes visual representatives of the master narrative through which we are guided into the Holocaust by someone who knows it only by its major landmarks, but also assumes the primacy of family, an idea stressed in the numerous texts written by survivors.

The family-centric viewpoint is not limited to the Survivor Narratives subcategory, however. The newly emerging sub-category of Bystander Narratives also stresses family as the key factor and often combines the stories of the bystander and the survivor, as in the film Toyland. This fourteen-minute film registers the master narrative from start to finish. As soon as the film opens, and Marianne enters her son's room to find him, we know that we are in 1940's Germany. Her hairstyle, clothing and language provide clues in the form of mise-en-scene. Once she steps into the hallway, however, the Holocaust master narrative becomes apparent as the story is

\footnotetext{
${ }^{41}$ Due to the imposed rules of representation, the sin qua non of the Holocaust is such that it demands realistic portrayals of Holocaust history.
} 
largely told in images rather than words. A Star of David is painted on the neighbor's door, an indicator that the household is not only Jewish but that they have been taken away by the Nazis. Marianne confirms this when she steps into the room and finds the place destroyed and the inhabitants missing. On the street, she encounters not just oblivious German citizens but a German police officer, who inquires as to whether she is Jewish before he will help her find her son. He tells her that they have only taken Jews to the train station so her son cannot be among them. The fact that his initial response is to determine her level of Jewishness coupled with the reference to the trains establishes in the audience's mind that, at three and a half minutes in, we are watching a film about the Holocaust. However, as with many of the other films mentioned herein, this film relies heavily on the existence of the master narrative to provide the details of the story that take place off-screen. The policeman's reference to the trains acts as a metaphor for concentration camps and Marianne is suitably terrified that her son has been deported to a place where children have no value and are immediately put to death. This knowledge is shared with the audience through the visual and linguistic signifiers of the master narrative which allow the viewer to pull from his or her own knowledge rather than have the filmmakers explicate the entirety of the Final Solution. Without this language of history, the viewer cannot understand all that he is seeing.

When Marianne arrives at the train, the image of the monstrous Nazi greets her immediately. Two Nazi officers begin shouting at her, assuming she is Jewish. Once she shows them her papers, she is escorted to the train to retrieve her son. The master 
narrative then reveals more of the story than can take place on-screen in fourteen minutes. The cattle car door is pulled back and we see people crammed in together, standing in darkness. We know from the master narrative that the cars hold many people, packed in 'like sardines.' They will spend days taking turns sitting down; there will be no light, no air, no water. Some will die en route, others at their destination, but most will not survive. The audience knows all of these things prior to viewing the film and thus the film tells the story only with the assistance of the master narrative. When Marianne makes the split second decision to claim that her Jewish neighbors' son is her own, we are aware that she has put herself in extreme danger by doing so, and she has saved him from certain death, something she cannot do for his parents. Her resistance to the destruction of the Jews only emerges at the end of the film, her bystander status is then merged with her newfound role of rescuer and quiet resister.

By far, the most unusual, and somewhat disturbing, new category of Holocaust-related film are the non-survivor narratives. These stories, either directly or indirectly giving an account of a concentration camp, end in death. A Secret is the history of a man attempting to discover the source of his father's deepening melancholy long after the war. The protagonist, however, is not a survivor of the camps, as he was not born until after the incident in question. Francois' parents meet at the wedding of his father, Maxime, to his mother's sister-in-law, Hannah. Maxime does not try to hide the fact that he is sexually attracted to Tania and spends the next several years trying to have an affair with her. As the film progresses, the audience 
learns that the family is Jewish and that Maxime and Tania have worked very hard to hide this fact despite the war being over. We learn that it is because of this secret that Maxime feels guilty. As the Nazis close in on Paris, the family makes plans to escape, traveling in small groups rather than as a family. However, Maxime has flaunted his desire for Tania in Hannah's face since the day of their marriage and on the journey to freedom, she reaches a breaking point. At a small village café, Hannah exposes herself and her young son to the Nazis, by presenting both her real papers and the fakes given to her. Hannah and the boy are carted away to a concentration camp and Maxime and Tania immediately begin a relationship. It is during this time that Francois is conceived. Without the master narrative hovering over Hannah's actions, this film would have no meaning; it would be about an affair, a betrayal of a much different sort. Throughout the film, the Nazi threat is very much an aside that plays underneath Maxime's desire for Tania; the war and the disappearance of European Jewry is part of the secret and therefore is never openly discussed or even alluded to, except by the neighbor Louise. The most blatant scene of Nazi imposition is one in which Hannah sews the yellow star on her son's jacket, and which ultimately leads to a fight between Hannah and Maxime on the subject of Maxime's desire to deny his Jewish heritage in order to avoid Nazi persecution. The master narrative is essential to the understanding of this film and the motivations of the characters. Without it, the audience would not know that to deny his Jewishness during the war may mean he and his family survive the deportations. Denying it after the war means that he is in some way separating himself from the memory of Nazi occupation. Most importantly, 
however, the master narrative tells the story of what happens to Hannah and Simon following their arrest at the café. The boy will likely be killed immediately at the camp. Hannah may survive longer if she is able-bodied enough to work but will ultimately die as well. We are made aware that she makes the choice of horrific death and possible torture over living with her husband's desire for another woman by the existence of the master narrative and the filmmaker's employment of this assumed knowledge. Therefore, the film assists in demonstrating the use of the master narrative in both survivor and non-survivor tales. ${ }^{42}$

There are as many examples of the use of the master narrative in Holocaust film as there are filmic representations of the Holocaust and no two use the same information in the same ways. This chapter summarizes only a handful of the possibilities within the scope of Holocaust film, but demonstrates how the master narrative of the Holocaust remains omnipresent in storytelling on the subject.

\footnotetext{
${ }^{42}$ A Secret is only one of a new wave of non-survivor Holocaust cinematic narratives. Others include The Devil's Arithmetic, Spring 1941, The Boy In the Striped Pajamas and Death in Love. This category includes the narratives of Jews who eventually perish in the camps but also those who were not survivors because they managed to escape deportation and are therefore survivors of a different kind.
} 
Chapter Five: The Signifier Signifying Nothing: The Rhetoric of the Unspeakable in Holocaust Discourse

The difficulties of representing trauma in fictional narrative in general are further complicated, with regard to Holocaust representation, by a pair of assumed restrictions placed over and above the master narrative itself. The first, that of who may create a Holocaust narrative, envisions a world in which the right to make film or write novels about the Jewish experience during the war is the exclusive dominion of those who either lived through it, or are descendants of the victims and survivors, or, at the very least, are Jewish, and therefore maintain a shared right to the cultural memory. Fundamental to this thinking is the idea that memory is sacred and that Holocaust memory can only be collected into cohesive narrative form by those who have an intimate connection with the event as separate from all other history. Therefore, the many and varied critiques of Schindler's List do not fault Spielberg's right to make the film, as such - only that the execution of his representation is unacceptable in light of its subject matter.

The second layer of limitations, then, is that of how Holocaust memory may be represented and presented to the public at large. While most critics agree that there should be limits to the types of representation available when creating Holocaust narrative, these limitations are not widely agreed upon in character. Adorno's statement on the barbarity of poetry "after Auschwitz" in the late 1940's was taken by some to mean an invocation of silence directed at survivors and non-survivors alike, although this was a very distorted interpretation of the statement Adorno made. Saul 
Friedlander reminds us that for two decades after liberation "Adult contemporaries of Nazism still dominated the public scene. Even the survivors chose to remain silent, since very few people were interested in listening to them (even in Israel) and since, in any case, their own main goal was social integration and a return to normalcy."

(2000:5) Given this desire, we can see that almost immediately following liberation of the camps, the 'unspeakability' mythology began. Due to the nature and magnitude of the destruction of the European Jews, the incomprehensibility of such an act left many speechless and unable to assimilate the reality of such an atrocity, but does the desire not to discuss tragedy and unfathomable loss of life translate into its being unspeakable?

Let us start with what is speakable in order to understand what it is not. Following the Holocaust, the rallying cry amongst survivors and the Jewish diasporic community as a whole was "never again." Inherent in this statement is the idea that the survivors would act as witnesses to history and that they would tell all that happened so that a Holocaust-like act could never again be committed without the world intervening and stopping it before its commission. In the Fortunoff Video Archive for Holocaust Testimonies at Yale University, survivors share their desires to relate what happened to anyone who would listen. Helen K. states that "We wanted to survive so as to live one day after Hitler, in order to be able to tell our story." ${ }^{, 43}$ Therefore, speakability lies in the act not only of witnessing, but of speaking that which has been witnessed. The idea that the Holocaust is inherently unspeakable, as

${ }^{43}$ Cited in Michael Levine's The Belated Witness: Literature, Testimony, and the Question of Holocaust Survival. Palo Alto, California: Stanford University Press, 2006, 1. 
the single most horrific event in contemporary history, cannot hold true for two important reasons. First, there is no physiological restriction on speech after trauma which is applicable to all human beings. That some are made speechless by traumatic events is due to individual mental processes rather than anything that is inherent in the human brain. Second, that some have spoken about the Holocaust from its occurrence, and continue to do so, negates the possibility that the speakability of the Holocaust is something that is restricted as a matter of course in all human beings, in all corners of the earth. Therefore, for those witnesses and survivors who find themselves able to articulate the trauma, the 'unspeakability' of the Holocaust must be a condition imposed by forces outside of themselves. It is not the events themselves that restrict our ability to speak them, but the encumbrance of a sacred mythology on those who wish to speak. In his Bradley Lecture, Dr. Walter Reich relates the story of a schoolteacher berated for answering truthfully a child's question regarding the numerical tattoo on her forearm, demonstrating the imposition of the sacrosanct on individual memory. While Elie Wiesel has made it his life's work to restrict the types of representation allowed for such an event as the Holocaust, as well as indicating a restriction on who is allowed to do so. It seems at cross-purposes to find fault in nearly every cinematic representation of the Holocaust for the sole reason that they are visual representations. Wiesel argues that, “...the Holocaust as filmed romantic adventure seems to me an outrage to the memory of the dead, and to sensitivity." (Wiesel, Shadows, xii). This is true of many films with the Holocaust as their subject matter, but should not, as a rule, be applied to all. In addition, to attempt to restrict 
film on such a massive scale seems futile. Wiesel's point is certainly valid in that the commodification of the Holocaust in recent decades, and even the perversion of the word itself, is especially troubling and threatens to trivialize the Holocaust as an event in the public's memory; however, there cannot realistically be any restriction on artistic expression. The fact that so many artists are attempting to create Holocaustrelated works denies the possibility of its continued unspeakability.

Naomi Mendel states that "....it is worth considering the extent to which the presumed 'unspeakable' quality of the Holocaust — a quality usually associated with the sacred, with the ineffable, and with the challenge to ethics and aesthetics posed by scenes of mass suffering and death - is a cultural construct, less a quality of the event itself than an expression of our own motivations and desires." (205) The rabbi, in inflicting his inclination for unspeakability on the schoolteacher, denies her the possibility of coming to terms with her experiences in a way that works for her, just as it denies the possibility of 'never again' as it becomes infinitely more possible to repeat a history we do not know or understand.

Setting aside the religious connotations of the word Holocaust, ${ }^{44}$ and the implication that Nazi intentions included burnt offerings, the Holocaust, as an event in Jewish history rather than world history has taken on a mythological significance that allows for the separation of the Jewish people from the rest of the world in terms of

\footnotetext{
${ }^{44}$ In the Hebrew language, Holocaust means a sacrificial fire. This implies that the Jews were offered as a sacrifice to God. The Nazis had no such thing in mind nor was the ever even hinted at in the multitude of explanations for the Final Solution. Currently, there is a debate over whether 'Holocaust' should even be applied to this event. See the Holocaust Encyclopedia on the United States Holocaust Memorial Museum website. http://www.ushmm.org/wlc/en/article.php?ModuleId=10005143.

However, this issue is referred to in many readings in the attached bibliography.
} 
Holocaust discourse. The rabbi noted above is only one of a large group of Jews following the war who refused to allow either survivors or the rest of the world the liberty of discussing the destruction of European Jewry without penalty. When Theodore Adorno proclaimed that "To write poetry after Auschwitz is barbaric," (xv) those who, like Wiesel or the rabbi above, were of the mind that the Holocaust should not be spoken of, attached the phrase to their cause, limiting the acceptability of any art or culture after Auschwitz. Poetry, in this case, then acts as a metaphor for artistic trivialization of trauma while Auschwitz serves as metaphor for human suffering in general, and the Holocaust in particular. The fact that the quote is misused and taken out of context only adds to the mythology. Were such a phase not needed to sum up the feelings of the advocates of unspeakability, it would not be so widely used. However, this also points to a strange dichotomy. On the side of unspeakability, there are those who, like Claude Lanzmann, believe that restrictions on the representation of the Holocaust are not only warranted but inherent in the event itself, contrary to survivor, Helen K.'s testimony. Lanzmann states, “The Holocaust erects a ring of fire around itself, a borderline that cannot be crossed because there is a certain amount of horror that cannot be transmitted. To claim it is possible to do so is to be guilty of the most serious transgression.” (1994:14) For Lanzmann, unspeakability and unrepresentability are identical ideologies, claiming that it is the "certain absolute of horror that is untransmissible." His film, he claims "is not made with memories: I knew that immediately. Memory horrifies me. Memory is weak." ${ }^{45}$ Lanzmann's

45 Cited in Dominick LaCapra's "Lanzmann's Shoah: Here There is No Why” Critical Inquiry, Vol. 
position is not to use newsreel footage from the liberation as was done in Night and Fog, nor to recreate the scenes of trauma as if the audience were viewing the actual events, as in Schindler's List, but to force the witnesses to relive the events in the present, to conflate the gap between past and present into a contiguous unit wherein the past is omnipresent.

On the side of the need to give voice to the traumatic events of the Holocaust, there is an inability to do so without either first explaining one's reasons for dismissing the unspeakability restrictions or defending the right to do so after the fact. Friedlander argues against the recent wave of interest in the Holocaust as the subject of fictional narrative and political rhetoric, asking the question "Doesn't that ever spreading reference mean an ever growing dilution, and ever growing simplification, and ever growing vulgarization?" (2000:10) His argument is against the de-valuation of the Holocaust into a form of kitsch, a trivialization of trauma in order to attach value to an unrelated event. Wiesel agrees. "They get a little history, a heavy dose of sentimentality and suspense, a little eroticism, a few daring sex scenes, a dash of theological rumination about the silence of God and there it is: let kitsch rule in the land of kitsch, where at the expense of truth, what counts is ratings and facile success." (NYTimes online, 1989) As Walter Reich points out, a quick search of the internet reveals the 'ever spreading reference' to which Friedlander refers.

"For example, there are sites for the Waco Holocaust, the Abortion Holocaust, the Kashmir Holocaust, the Bangladeshi Holocaust, the Hindu Holocaust, the Taiwanese Holocaust, the Assyrian Holocaust, the Greek Holocaust, the Kirishtan Holocaust of Japanese Christians. There are websites in which Scientologists 
compare their experiences in contemporary Germany to that of the Jews in Nazi Germany.” (Reich, Bradley Lecture, online)

Friedlander's anxiety is certainly justified given the above, but it is even more so when combined with the American propensity to attach the word 'Holocaust' to any political debate in order to raise the perception of their own victimization, or that of others. Some of these include uses in media coverage of environmental disasters (Whale Holocaust), vegetarian rhetorical debate (Chicken Holocaust), and protests against government intervention (the Herbal Holocaust). Worse yet is the use of Holocaust statistics as a way of turning the tragedy into a useful commentary on one's own research. Sociologist Gabriel Schoenfeld asserts that the Holocaust needs decentering from its humanist ideology because "the environmental impact of thousands of pounds of human ash dumped into lakes and rivers is no less urgent a subject than the Holocaust itself." ${ }^{, 46}$

At the same time, Jean-Luc Godard implies that the proliferation of cinematic kitsch is the byproduct of the Hollywood paradigm. He agrees with Lanzmann in that film should not seek to recreate events of the past in a way that makes the audience feel as though they are part of the narrative. However, his argument deviates from Lanzmann's in key respects. Godard believes that Holocaust film should not seek to conflate the passage of time. He is not "against the image per se and is not grounded in the visual taboo propagated by Wiesel, Adorno and Lanzmann, amongst others; he has no qualms about including images of the camps" (Wheeler, 187). His own films never allow the viewer to step into the real, they are constantly reminded that what

${ }^{46}$ Cited in Reich's Bradley Lecture. See List of References. 
they are watching is a film about the Holocaust made by a director whose subjectivity is unquestionable. "For Godard, a film such as Schindler's List is dishonest not only because it attempts to conceal its own subjectivity but also because through Hollywood's hegemony it silences other voices." (Wheeler, 188) In other words, his argument is against films like Schindler's List acting as the master narrative for Holocaust representation. His disdain for the Hollywood film becoming the yardstick by which history is measured has merit in that the Hollywood industry exists not for its own pleasure nor for artistic quality necessarily, but as a commercial entity. Therefore, accuracy is not paramount to a film like Schindler's List and therefore the memories Spielberg draws upon need not be questioned for their legitimacy, but merely for their storytelling value. "Godard's objection is not the specific memories that Spielberg chooses but the fact that these memories are insufficiently analysed [sic] and are manipulated to yield a film that purports to reproduce fact." (Wheeler, 191) He questions not only the subjectivity of the directors of fictional film narrative but that of the witnesses who go unquestioned.

It is this taboo against analysis of witness testimony that is paramount for some critics and philosophers. The anxiety that prompts Saul Friedlander to pose the question "Is it not unacceptable to debate formal and abstract issues in relation to this catastrophe?" (1996:1) is similar to that discussed by David Bathrick on the use of comedy with relation to the Holocaust. "Certainly the initial reception of Life is Beautiful threw into question and at least temporarily destabilized a number of received notions about representational propriety. The first, and ...most pressing issue 
concerned the matter of employing a comedic mode to deal with such a topic." (42) For Friedlander, Lanzmann and Adorno, such a thing cannot be considered. Yet, for Benigni, the story is told from the perspective of a child who, later in life, recognizes that the fact that his father kept his comedic perspective even after entering Auschwitz is what saved him from the possibility of deeply traumatic memory. Contrary to popular critical perception, the story is not told as a comedy, as if to say 'the Holocaust was funny.' Instead, it is a story about a little boy and his father who do what is necessary to survive and since the character of Guido is naturally comedic before Auschwitz, there is no reason to believe that he would change his survival tactics after entering the camp.

Though the arguments against representation appear to cover every possible aspect, the many-sided debate has not stopped, or even slowed, cinematic representation of the Holocaust, nor, indeed, any other type of representation. In recent years, Holocaust representation has taken on new dimensions, reaching the point of being ubiquitous. The unspeakability restrictions which have plagued writers, filmmakers, artists and poets are beginning to become problematic in an era of social media and constant information transfer. The shroud of sanctity afforded Holocaust memory for sixty-five years is falling away and giving rise to a new ideal wherein the goal is to document and record everything, every memory is becoming a necessity, and therefore vital in the discourse. However, at the same time, "Questions about the ethics of representation are gaining urgency at a time when ever more diverse forms of Holocaust representation are emerging worldwide, and particularly in cinema." 
(Saxton, 3) Therefore, as the desire to speak the unspeakable overpowers the restriction on doing so, the emphasis must change from "prohibition and taboo to permission and responsibility." (Saxton, 2) That is, continuation of the rules of unspeakability appears to be impossible given the sheer number of representations of the Holocaust, therefore it is time to urge debate on responsible representation. No longer should there be a taboo that disallows the victim to be heard.

Gillian Rose sums it up well. "To argue for silence, prayer, the banishment equally of poetry and knowledge, in short, the witness of 'ineffability', that is, nonrepresentability, is to mystify something we dare not understand, because we fear that that it may be all too understandable, all too continuous with what we are-human, all too human." (43) 
Chapter Six: Conclusion

While the documentation of the preceding debate is interesting in and of itself, I use it here to indicate that the master narrative, with respect to the Holocaust, is not limited to the elements of the narrative matrix, but carries with it the debate over its very representation. Indeed, the discussion of the Holocaust as an area of research in any academic discipline is inseparable from discussion of the debate about its representation. Books such as The Belated Witness by Michael Levine, Auschwitz by Laurence Rees, Haunted Images by Libby Saxton and Can One Live After Auschwitz? by Theodor Adorno all begin with introductory chapters wherein the author weighs in on his viewpoint and associates himself with a particular ideology within the argument. Regardless of the divergent disciplines from which these texts arise, Sociology, History, Film and Philosophy, the common thread, apart from subject matter, is that all feel the need to address the debate prior to their own analysis. The 'limits of representation' made primary by Saul Friedlander, Elie Wiesel and many others have become so obligatory and insidious a part of the master narrative that there is no longer any objective analysis without acknowledgement that the author is doing something against which there is a taboo.

Although the same restrictions exist in the field of filmmaking, there the debate takes visual form and thereby enjoins the viewer to accept the director's opinion as an additional element of his subjective viewpoint. Therefore, the Holocaust master narrative consists of that which we believe we know about the destruction of European Jewry during WWII, and that which we believe we know about the debate surrounding 
the acceptability of certain forms of representation. Following the release of Schindler's List, various critics refused to see the film due to its commercial success. Argument raged over the film's accuracy, style, and most especially, form.

Schindler's List sought to make the memory of the Holocaust real for those of us who had not witnessed it ourselves. Thereby it sought to create a pseudo-reality in which we might inhabit a concentration camp for three and a half hours and still have the luxury of going home afterwards. The goal was to fool the audience into the false perception that the events in the film had been captured as they occurred. It was Spielberg's use of the master narrative to recreate Plaszow in vivid detail, including the personage of Amon Goeth, that ignited the debate that followed. The debate was so frenzied that the idea that a viewer could enter the theater without at least some knowledge of the drama surrounding the film was highly improbable. Therefore, the viewer was obliged to acknowledge the debate as part of the film-going experience, although the audience's recognition of the non-diegetic master narrative may not be any more consciously registered than the diegetic elements of the master narrative.

If, as Godard implies, the master narrative is laid out by Schindler's List, and I would argue, Holocaust, Night and Fog and Shoah, then any film that addresses the Holocaust after these representations ${ }^{47}$ must acknowledge the master narrative as it seeks to revise it, for all film following the formation of the master narrative must be seen as revisions in that the four films listed above impart to the audience only a tiny fragment of the possibilities available in Holocaust narrative. Moreover, as the future

\footnotetext{
${ }^{47}$ In the context of this thesis, we are discussing American films or films for which an American audience is intended.
} 
life of the Holocaust history, as told by Hollywood, begins to embroider the fabric of the master narrative and the matrix becomes richer, these revisions will begin to create an overall more accurate history of the real. Film will always be in the realm of representational reality since the audience is never unaware that they are sitting in a movie theater watching a film, but as the master narrative expands to include films that augment the initial master narrative matrix, the representations will necessarily become less about the films as separate entities and more about the history they represent.

Therefore, the master narrative can be understood to be the apex of multiple parallax views. That is, the master narrative allows for the blending of views of empirical history, historical interpretation and subjective personal accounts which, as a whole, give a fuller, though not necessarily more accurate, account of events. Through the use of the master narrative in literature and film, the author or filmmaker brings the audience into the story in a way that relies on emotional response and is more personal than purely scientific accounts of history. Without the master narrative, audiences would be subject to multiple, and possibly contradictory, accounts of history on film and while there are vast possibilities for interpretation of events, the master narrative provides an anchor by which to orient ourselves within the context of the story being told. As filmgoers, we have a certain amount of faith that the events in the film will follow the path on which we have laid our knowledge of history and believe that the film will erect the requisite signposts along the journey. 
References

Adorno, Theodor. Can One Live After Auschwitz? A Philosophical Reader. Ed. Rolf Teidermann. Trans. Rodney Livingstone, et al. Stanford, CA: Stanford University Press, 2003.

Alexander, Jeffrey. "Toward a Theory of Cultural Trauma." in Cultural Trauma and Collective Identity, edited by J. Alexander, et, al., pp. 1-30. Berkeley: University of California Press, 2004.

Alvarez, Alexander. "Adjusting to Genocide: The Techniques of Neutralization and the Holocaust" Social Science History, Vol. 21, No. 2 (Summer, 1997), pp. 139-178

Arendt, Hannah. Eichmann in Jerusalem: a report on the banality of evil. New York: Viking Press, 1963.

Barthes, Roland. "The Reality Effect" French Literary Theory Today. Ed. Tzvetan Todorov. Cambridge: Cambridge University Press, 1977.

Bartov, Omer. "Germany as Victim” New German Critique, No. 80, (SpringSummer, 2000), pp. 29-40

Bathrick, David. "Rescreening 'The Holocaust': The Children's Stories" New German Critique, No. 80 (Spring-Summer, 2000), pp. 41-58

Card, Claudia. "Rape as a Weapon of War" Hypatia. Vol. 11, Issue 4, November 1996, pp. 5-18.

Caruth, Cathy. "Introduction" in Trauma: Explorations in Memory. Cathy Caruth, ed., Baltimore: John Hopkins University Press, 1995.

Diken, Bulent and Carsten Bagge Lausten. "Becoming Abject: Rape as a Weapon of War" Body \& Society Vol. 11, 2005, pp. 111-128.

Doneson, Judith. "Holocaust Revisited: A Catalyst for Memory or Trivialization?" Annals of the American Academy of Political and Social Science, Vol. 548 (November 1996), pp. 70-77

---. The Holocaust in American Film. Philadelphia: The Jewish Publication Society, 1987.

Dubiel, Helmut. " The Remembrance of the Holocaust as a Catalyst for a Transnational Ethic?” New German Critique, No. 90 (Autumn, 2003), pp. 59-70 
Eisikowitz, Michael. "The Brides of Bergen Belsen.” Online. Holocaust Studies. http://www.aish.com/ho/p/100468809.html. August, 14, 2010. Originally published in Mishpacha Magazine.

Felman, Shoshana. "In an Era of Testimony: Claude Lanzmann's Shoah" Yale French Studies, No. 79 (1991), pp. 39-81

Finke, Laura A., and Martin B. Shichtman. Cinematic Illuminations. Baltimore: Johns Hopkins University Press, 2010.

Fletcher, George. "The Storrs Lectures: Liberals and Romantics at War: The Problem of Collective Guilt" The Yale Law Journal, Vol. 111, No. 7 (May, 2002), pp. 14991573

Foucault, Michel. Aesthetics, Method, and Epistemology, Vol. 2. Ed. James D. Faubion, Trans. Robert Hurley, et al. New York: The New Press, 1994.

---. "Nietzsche, Genealogy, History.” In Language, Counter-Memory, Practice:

Selected Essays and Interviews. D. F. Bouchard, ed., pp. 139-164. Ithaca: Cornell University Press, 1977.

Friedlander, Saul, ed. Probing the Limits of Representation: Nazism and the "Final Solution." Cambridge, Mass: Harvard University Press, 1992.

---. "History, Memory and the Historian: Dilemmas and Responsibilities" New German Critique, No. 80, (Spring-Summer, 2000), pp. 3-15

Gold, Trudy. "An Overview of Hollywood Cinema's Treatment of the Holocaust" in Holocaust and the Moving Image. Eds. Toby Haggith and Joanna Newman. London: Wallflower Press, 2005, pp. 193-197.

Hansen, Miriam Bratu. "'Schindler's List' is Not 'Shoah': The Second Commandment, Popular Modernism, and Public Memory” Critical Inquiry, Vol. 22, No. 2 (Winter, 1996), pp. 292-312.

Hayden, Robert M. "Schindler's Fate: Genocide, Ethnic Cleansing and Population Transfers" Slavic Review, Vol. 55, No. 4 (Winter, 1996), pp. 727-748

Hilberg, Raul. The Destruction of the European Jews. New York: Holmes and Meier Publishers, 1985.

Hirsch, Joshua. After Image: Film, Trauma and the Holocaust. Philadelphia: Temple University Press, 2004 
Insdorf, Annette. Indelible Shadows: Film and the Holocaust. Cambridge: Cabridge University Press, 1983.

Jokic, Aleksander. "Genocidalism" The Journal of Ethics, Vol. 8, No. 3 (2004). pp. 251-297.

Kansteiner, Wulf. "Entertaining Catastrophe: The Reinvention of the Holocaust in the Television of the Federal Republic of Germany" New German Critique, No.90 (Autumn, 2003), pp. 135-162

Koepnick, Lutz. " Reframing the Past: Heritage Cinema and Holocaust in the 1990s" New German Critique, No.87 (Autumn, 2002), pp. 47-82

LaCapra, Dominick. "Lanzmann's Shoah: Here There is No Why" Critical Inquiry, Vol. 23, No. 2 (Winter, 1997), pp. 231-269.

Lambert, Peter and Phillipp Schofield eds. Making History: An Introduction to the History and Practices of a Discipline. New York: Routledge, 2005.

Langer, Lawrence L., ed. Art From the Ashes. New York: Oxford University Press, 1995.

Lanzmann, Claude. Shoah: The Complete Text of the Acclaimed Film. New York: De Capo Press, 1995.

Lanzmann, Claude. "Why Spielberg Distorted the Truth." Guardian Weekly, 3 April 1994, p. 14.

Lemkin, Raphael. "Genocide as a Crime Under International Law" The American Journal of International Law, Vol. 41, No. 1 (January, 1947), pp. 145-151

Levi, Primo. Survival in Auschwitz. Trans. Stuart Woolf. New York: Simon and Schuster, 1958.

Levine, Michael. The Belated Witness: Literature, Testimony, and the Question of Holocaust Survival. Palo Alto, California: Stanford University Press, 2006.

Libowitz, Richard. "Holocaust Studies" Modern Judaism, No. 10 (1990), pp. 271-281

Loshinsky, Yosefa. Spielberg's Holocaust: Critical Perspectives on Schindler's List. Bloomington, Indiana: Indiana University Press, 1997. 
Mendel, Naomi. "Rethinking 'After Auschwitz': Against a Rhetoric of the Unspeakable in Holocaust Writing" boundary 2, Vol. 28, No. 2 (2001), pp. 201-228

Morrow, Lance. "Time Essay: Television and the Holocaust." Editorial. Time 1 May 1978. Breaking News, Analysis, Politics, Blogs, News Photos, Video, Tech Reviews TIME.com. Time Warner, Inc. in Partnership with CNN. Web. 06 Feb. 2011. $<$ http://www.time.com/time/magazine/article/0,9171,919563-2,00.html>.

Moses, A.D. "Structure and Agency in the Holocaust: Daniel J. Goldhagen and His Critics" History and Theory, Vol. 37, No. 2 (May, 1998), pp. 194-219

Novick, Peter. The Holocaust in American Life. Boston: Houghton Mifflin Company, 1999.

Neitzsche, Friedrich. "On Truth and Lying in a Non-Moral Sense. The Norton Anthology of Theory and Criticism. Ed. Vincent Leitch. New York: W.W. Norton \& Company, 2001, pp. 874-884.

Rees, Laurence. Auschwitz: A New History. New York: Perseus Books Group, 2005.

Reich, Walter. "The Use and Abuse of Holocaust Memory" American Enterprise Institute for Public Policy Research, The Bradley Lectures. 14 Nov, 2005.

Rose, Gillian. Mourning Becomes the Law: Philosophy and Representation. Cambridge: Cambridge University Press, 1996.

Rosenstone, Robert A. "The Reel Joan of Arc: Reflections on the Theory and Practice of Historical Film” The Public Historian, Vol. 25, No. 3 (Summer, 2003), pp. 61-77

Saxton, Libby. Haunted Images: Film, Ethics, Testimony and the Holocaust. London: Wallflower Press, 2008.

Shrag, Calvin. "Otherness and the Problem of Evil: How Does That Which Is Other Become Evil?" International Journal for Philosophy of Religion, Vol. 60, No. 1/3, (Dec, 2006), pp. 149-156

Smith, David Norman. "The Social Construction of Enemies: Jews and the Representation of Evil" Sociological Theory, Vol. 14, No. 3 (November, 1996), pp. 203-240

Spalding, Roger and Christopher Parker. Historiography: An Introduction. Manchester: Manchester University Press, 2007.

Spiegelman, Art. Maus I. New York: Pantheon Books, 1973. 
---. Maus II. New York: Pantheon Books, 1986.

Stanford, Michael. The Nature of Historical Knowledge. Oxford: Basil Blackwell, 1986.

Stein, Arlene. "'As Far as They Knew I Came from France': Stigma, Passing, and Not Speaking about the Holocaust" Symbolic Interaction, Vol. 32, No. 1 (Winter 2009), pp. 44-60

Stimmel, Joanna. "Holocaust Memory Between Cosmopolitanism and NationSpecificity: Monika Maron's Pawel's Briefe and Jaroslaw Rymkiewicz's Umschlagplatz" The German Quarterly, Vol. 78, No. 2 (Spring 2005), pp. 151-171

Tilly, Charles. "Reasons Why” Sociological Theory, Vol. 22, No. 3 (Sep., 2004), pp. 445-454

Toplin, Robert Trent and Jason Eudy. "The Historian Encounters Film" $\underline{\mathrm{OAH}}$ Magazine of History, Vol. 16, No. 4, Film and History (Summer, 2002), pp. 7-12

Viano, Maurizio. "'Life Is Beautiful': Reception, Allegory, and Holocaust Laughter" Film Quarterly, Vol. 53, No. 1 (Autumn, 1999), pp. 26-34

White, Hayden. Metahistory: The Historical Imagination in Nineteenth Century Europe. Baltimore: Johns Hopkins University Press, 1973.

Wheeler, Duncan. "Godard's List: Why Spielberg and Aschwitz Are Number One" Media History, Vol. 15, No. 2, 2009, pp. 196-204.

Wiesel, Elie. "Art and the Holocaust: Trivializing Memory" New York Times online. 11 June, 1989.

http://query.nytimes.com/gst/fullpage.html?res=950DE6D6143BF932A25755C0A96F 948260\&pagewanted $=1$

---. The Night Trilogy. Trans. Marion Weisel. New York: Hill and Wang, 1972.

Windschuttle, Keith. The Killing of History. New York: Encounter Books, 1996.

Films Cited:

A Secret, created by Gerald Miller, dir. Gerald Miller, prod. Yves Marmion, Canal +, 2007. 
Coal Miner's Daughter, dir. Michael Apted, prod. Bernard Schwartz, Universal Pictures, 1980.

Holocaust: The Story of the Family Weiss, Part 1, created by Gerald Green, dir. Marvin J. Chomsky, prod. Herbert Brodkin, Titus Productions, NBC, 16 Apr. 1978.

Judgment At Nuremberg, dir. Stanley Kramer, prod. Stanley Kramer, Roxlom Films, Inc, 1961.

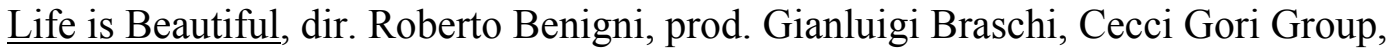
1998.

Night and Fog, dir. Alain Resnais, prod. Anatole Daumon, Argos Films, 1955.

Out of the Ashes, dir. Joseph Sargent, prod. Lee Levinson, Ardent Productions, 2003.

Schindler's List, dir. Steven Spielberg, prod. Steven Spielberg, Universal Pictures, 1993.

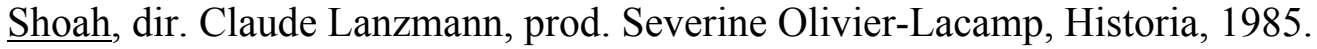

Spring, 1941, dir. Uri Barbash, prod. Rami Damri, Praxis Films, 2008.

The Devil's Arithmetic, dir. Donna Deitch, prod. Robert Avrech, Millbrook Farm Productions, 1999.

The Pianist, dir. Roman Polanski, prod. Robert Benmussa, Focus Features, 2002.

The Reader, dir. Stephen Daldry, prod. Jason Blum, Weinstein Company, 2008.

Toyland, dir. Jochen Alexander Freydank, prod. David Bunners, Mephisto Films, 2007.

Walk the Line, dir. James Mangold, prod. Alan Blomquist, Twentieth Century Fox, 2005. 